\title{
Review \\ Heme-Based Gas Sensors in Nature and Their Chemical and Biotechnological Applications
}

\author{
Ana Claudia Silva Gondim, Wellinson Gadelha Guimarães and Eduardo Henrique Silva Sousa *D
}

check for

updates

Citation: Gondim, A.C.S.; Guimarães, W.G.; Sousa, E.H.S. Heme-Based Gas Sensors in Nature and Their Chemical and Biotechnological Applications. BioChem 2022, 2, 43-63. https://doi.org/10.3390/ biochem 2010004

Academic Editors: Manuel Aureliano, M. Leonor Cancela, Célia M. Antunes and Ana Rodrigues Costa

Received: 20 December 2021

Accepted: 29 January 2022

Published: 8 February 2022

Publisher's Note: MDPI stays neutral with regard to jurisdictional claims in published maps and institutional affiliations.

Copyright: (C) 2022 by the authors. Licensee MDPI, Basel, Switzerland. This article is an open access article distributed under the terms and conditions of the Creative Commons Attribution (CC BY) license (https:// creativecommons.org/licenses/by/ $4.0 /)$.

\author{
Bioinorganic Group, Department of Organic and Inorganic Chemistry, Federal University of Ceara, \\ Fortaleza 60440-900, Brazil; acgondim@dqoi.ufc.br (A.C.S.G.); wellinson000@yahoo.com.br (W.G.G.) \\ * Correspondence: eduardohss@dqoi.ufc.br
}

\begin{abstract}
Sensing is an essential feature of life, where many systems have been developed. Diatomic molecules such as $\mathrm{O}_{2}, \mathrm{NO}$ and $\mathrm{CO}$ exhibit an important role in life, which requires specialized sensors. Among the sensors discovered, heme-based gas sensors compose the largest group with at least eight different families. This large variety of proteins also exhibits many distinct ways of sensing diatomic molecules and promote a response for biological adaptation. Here, we briefly describe a story of two impressive systems of heme-based oxygen sensors, FixL from Rhizobium and DevS(DosS)/DosT from Mycobacterium tuberculosis. Beyond this, we also examined many applications that have emerged. These heme-based gas sensors have been manipulated to function as chemical and biochemical analytical systems to detect small molecules $\left(\mathrm{O}_{2}, \mathrm{CO}, \mathrm{NO}, \mathrm{CN}^{-}\right)$, fluorophores for imaging and bioanalysis, regulation of processes in synthetic biology and preparation of biocatalysts among others. These exciting features show the robustness of this field and multiple opportunities ahead besides the advances in the fundamental understanding of their molecular functioning.
\end{abstract}

Keywords: heme-based gas sensors; DevS/DosT/DevR; FixL; bioanalytical tool; biotechnological applications

\section{Introduction}

Life is a complex web of connections, where no single organism lives in complete isolation. Chemical ecology is an obvious and essential feature that emerges from this, where a multitude of molecules are produced, released, absorbed and transformed all the time. Some of them can be very important while others are extremely harmful, which sometimes requires very sophisticated alert systems. The ability to sense and respond to some molecules is a way to adapt to environmental changes, a key feature of life. Among the various molecules required to be sensed, there are very simple and small ones such as diatomic molecules that can play critical roles in life. Molecules such as $\mathrm{H}_{2}, \mathrm{~N}_{2}, \mathrm{O}_{2}, \mathrm{NO}$ and $\mathrm{CO}$ have many biological uses, and sensing systems have been found for most of them, regulating their processes [1-4].

Nature has developed exciting proteins capable of selectively binding and recognizing diatomic gases, distinguishing one single atom of oxygen from nitrogen or carbon in the triad of gases: $\mathrm{O}_{2}, \mathrm{NO}$ and $\mathrm{CO}[2,5]$. Their chemical properties as tiny gaseous molecules make it harder for proteins to bind them [1]. Indeed, most of the protein sensors for these gaseous molecules employ metal centers that are capable of making a direct bond with them. Actually, there are many highly stable metal-based compounds containing one or more $\mathrm{CO}$ or NO as ligands, including in metalloprotein sites (see hydrogenases, nitrogenases [6]). The use of metal ions, particularly of iron in proteins, allows sensors to interact more efficiently with $\mathrm{O}_{2}, \mathrm{NO}$ or $\mathrm{CO}$. Indeed, their binding strength can vary widely (from picomolar to micromolar), opening opportunities to probe a large range of concentrations. The most common nature of these iron-based sensing units is mononuclear iron, binuclear iron, iron-sulfur cluster or heme sites [1]. These four distinct types of iron-based sites have been 
found in many systems such as NO sensor NorR from Escherichia coli (mononuclear iron site) [7], $\mathrm{O}_{2}$ sensor $V c B h r-D G C$ from Vibrio cholerae (binuclear iron site, hemerythrin-like) [8], $\mathrm{O}_{2}$ sensor FNR from Escherichia coli (iron-sulfur cluster site $\left[\mathrm{Fe}_{4} \mathrm{~S}_{4}\right]$ ) [9] and $\mathrm{O}_{2}$ sensor FixL from Rhizobium (heme site) [10] (Figure 1). Regarding their structural organization, these metal-based sensing units have been found within a certain region of the protein, in a different domain or as a completely independent protein (Figure 1). This organizations can be exemplified by three metalloprotein gas sensors:

1. Single domain: Whib3, an $\mathrm{NO} / \mathrm{O}_{2}$ sensor from Mycobacterium tuberculosis, exhibits an iron-sulfur cluster site (sensing unit) and a DNA-binding region (responsive unit) within the same protein region (Figure 1) [9].

2. Different domains: FixL, an $\mathrm{O}_{2}$ sensor from Rhizobia bacteria, contains a heme site (sensing unit) and a histidine kinase region (responsive unit) in different domains (Figure 1) [3].

3. Independent proteins: $\mathrm{PaNosP}$, an NO sensor from Pseudomonas aeruginosa, presents a heme-containing protein (sensing unit) that functions by regulating another independent histidine kinase protein (responsive unit) (Figure 1) [11].

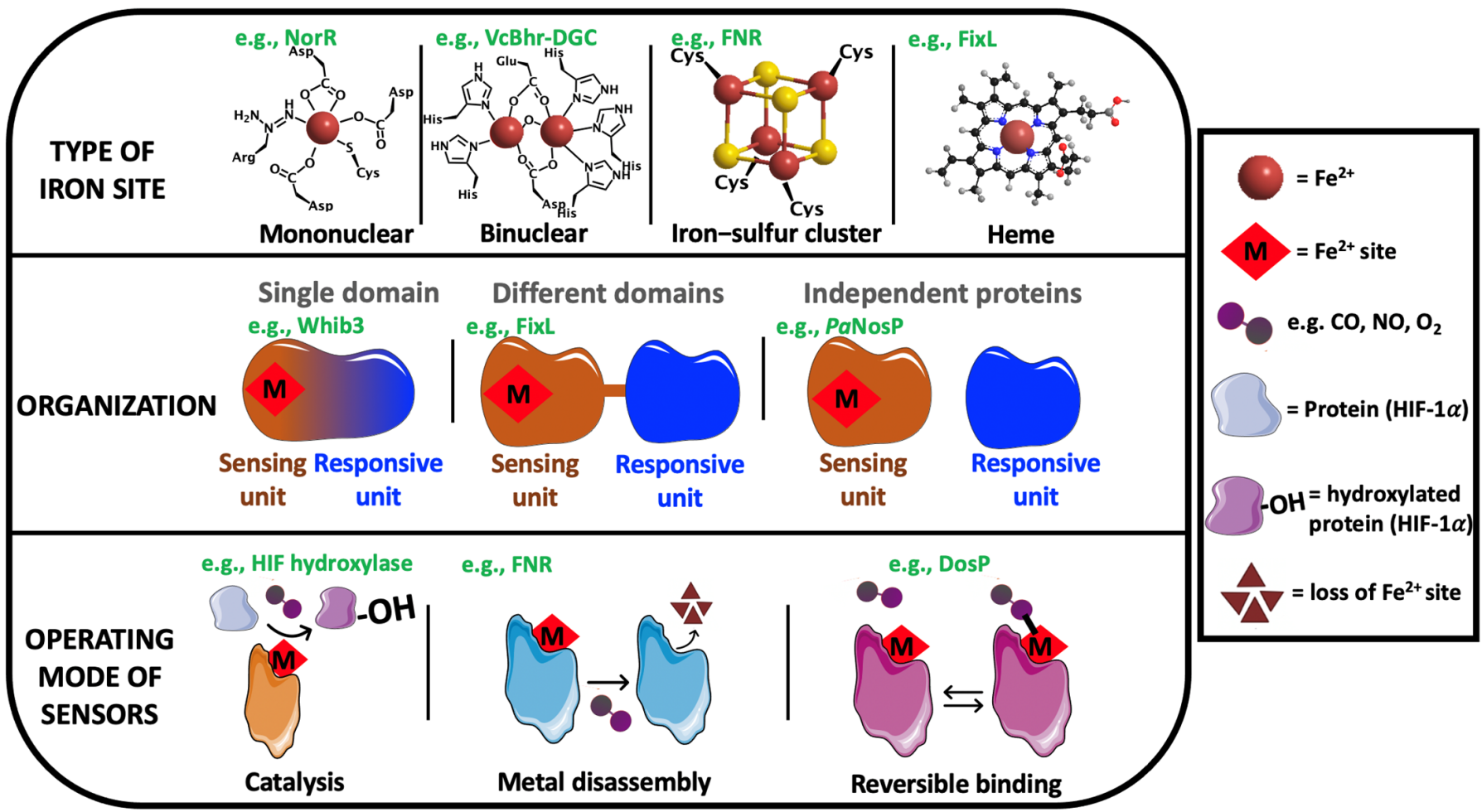

Figure 1. Basic building blocks of metal-based sensor proteins for $\mathrm{O}_{2}, \mathrm{NO}$ and $\mathrm{CO}$ and molecular functioning. Firstly, four types of iron sites are briefly illustrated with examples of gas sensors: mononuclear iron site of the NO sensor NorR from E. coli, binuclear iron site of the $\mathrm{O}_{2}$ sensor BhrDGC from Vibrio cholerae, iron-sulfur cluster of the $\mathrm{O}_{2}$ sensor FNR from E. coli, and heme iron site of the $\mathrm{O}_{2}$ sensor FixL from Rhizobium. Then, it shows the overall organization of metal-based gas sensors with three distinct structural features along with examples such as Whib3 from Mycobacterium tuberculosis as a single protein sensor of $\mathrm{NO} / \mathrm{O}_{2}$, FixL as a multi-domain $\mathrm{O}_{2}$ sensor and $\mathrm{PaNosP}$ from Pseudomonas aeruginosa with independent protein units functioning as an NO sensor and the responsive unit. The different general modes of operation of metal-based gas sensors are illustrated, where the first case involves catalysis using $\mathrm{O}_{2}$ as shown by the $\mathrm{O}_{2}$ sensor HIF hydroxylase. The next mode employs iron-sulfur cluster site disassembly represented by the $\mathrm{O}_{2}$ sensor FNR, while the last case involves reversible binding to the gaseous signaling molecule as illustrated by the $\mathrm{O}_{2}$ sensor DosP. 
There are also many types of metallosensing units based on how they respond to the biological signal, as described elsewhere [1]. However, most of them function as a catalytic unit, a metal disassembling unit or a reversible binding unit [1] (Figure 1). The $\mathrm{O}_{2}$ sensor HIF hydroxylase from Homo sapiens functions by catalyzing $\mathrm{O}_{2}$-based hydroxylation of HIF-1 $\alpha$ (a transcription factor), leading to its degradation, turning off a genetic hypoxia response [12,13]. Iron-sulfur cluster unit found in the $\mathrm{O}_{2}$ sensor FNR from E. coli function by reacting with $\mathrm{O}_{2}$ disassembly of the iron site $[9,14]$. However, many types of metalloprotein gas sensors function upon reversible and direct binding of the gaseous signal to the metal site such as $\mathrm{O}_{2}$ sensor FixL that employs a heme cofactor for reversible binding [3]. Besides all of that, a validated sensing unit upon binding to these gaseous molecules must report such process to a responsive unit (also known as a functional output structure), leading to biological adaptation.

The responsive unit is another essential part of these gas sensors, being involved in the conversion of the gas binding process into a biochemical signal/information. Similarly to the sensing unit, it can also be found as part of a certain region of the protein, in one different domain or in another independent protein (Figure 1). There are many functional output units used by nature: those with enzymatic activity (e.g., histidine kinase [10,15,16], nucleotide cyclase [17-19], phosphodiesterase [18,19]), capable of interacting with a protein or DNA and others [20], meaning that the binding of $\mathrm{O}_{2}, \mathrm{NO}$ and $\mathrm{CO}$ can regulate the production or degradation of molecules (e.g., c-di-GMP by DosC/DosP impacting RNA [21,22]) or the interaction with a DNA sequence enabling gene regulation (e.g., CooA [23]) or modification of a protein for degradation (e.g., HIF hydroxylase [24]), among other things $[1,2,20]$. These intricate arrangements have allowed nature to come up with many outstanding biological responses, regulating multiple processes as important as blood pressure, biological clock, nitrogen fixation, dormancy, bacterial biofilm, RNA degradation, virulence, among others. Unfortunately, a detailed structural mechanism of the signal transduction processes is still mainly lacking, but some important insights have emerged, as mentioned briefly here and in detail elsewhere [1,2,20,25-29].

The largest family of metalloprotein gas sensors is based on heme-containing proteins [4]. These heme-based gas sensor proteins have been commonly found containing multi-domains (e.g., FixL, DosP), but there are also standalone proteins as well (e.g., PaNosP, Figure 1) [30]. Soluble guanylate cyclase (sGC) was the first discovered case of a heme-based gas sensor protein, which functions as a dedicated nitric oxide (NO) sensor [17,31]. This protein contains a heme domain, one intervening domain and an enzymatic domain that converts GTP into the second messenger cGMP and pyrophosphate $\left(\mathrm{PP}_{\mathrm{i}}\right)$. This enzymatic activity is strongly enhanced upon NO binding to the heme domain, leading to major production of cGMP [17]. This latter molecule is a secondary messenger involved in the regulation of many physiological processes [32]. Actually, sGC is involved in many important processes in humans and other organisms, including vasodilation, platelet aggregation, memory, etc. [33,34]. 
In 1991, Gilles-Gonzalez discovered another heme-based gas sensor called FixL [10]. This protein was shown to be an $\mathrm{O}_{2}$ sensor. FixL is an important upstream oxygen sensor for Rhizobia bacteria, which allows symbiosis to occur with leguminous plants [35]. That important discovery was soon followed by others, supporting the existence of a superfamily of heme-based gas sensors. Currently, there are at least eight major families of these sensors based on the heme fold domain, which includes the PAS, HNOB (or HNOX), globin, CooA (CRP), SCHIC, GAF, LBD (Holi) and FIST domains (Figure 2) [36,37]. This latter family is the most recent one discovered in 2017 [11], whose sensors are called NosP (nitric oxidesensing protein). The most common diatomic gas type sensed by each family is shown in Figure 2, along with some well-known protein sensors and their biological functions.

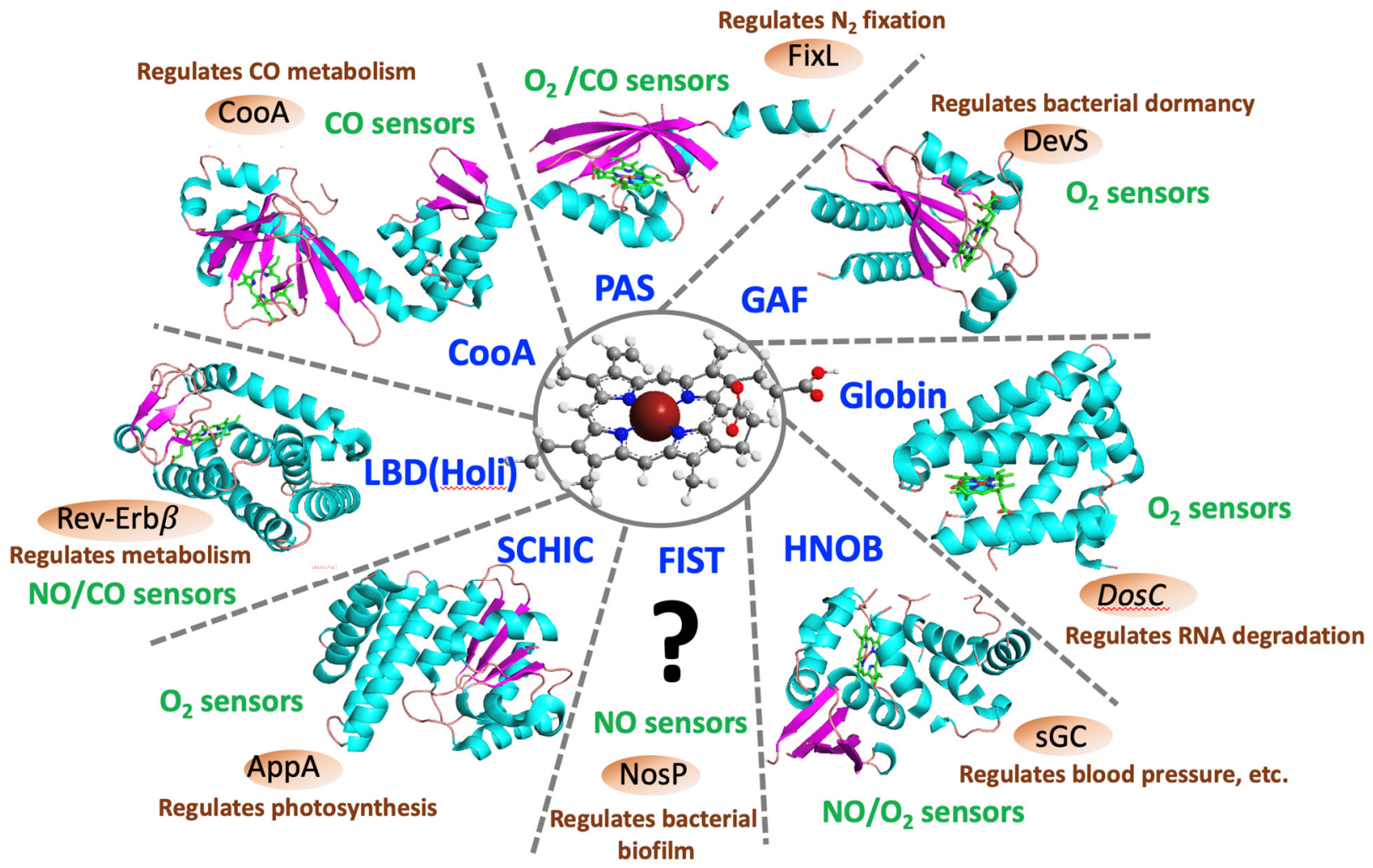

Figure 2. Heme-based gas sensor families, structural heme fold (in blue; PAS domain (pdb 1DP9), GAF domain (pdb 4YNR), globin domain (pdb 6OTD), HNOB domain (pdb 2O09), FIST domain (3D structure not solved yet), SCHIC domain (pdb 4HEH), LDB(Holi) domain (pdb 3CQV), CooA domain (pdb 2FMY)), common functionality as a gas sensor (green) and some examples of proteins of each family (brown oval) and biological function (brown).

\section{FixL-A Short Story}

Nitrogen fixation promoted by some bacteria is a very important process that allows proper access of a nitrogen source to plants during a symbiotic process [35,38]. This process is usually complex, and nitrogenases are also oxygen-sensitive, requiring many physiological changes to happen within the plant nodule and Rhizobia [38]. The plant is responsible for building an oxygen barrier in the nodule along with a large production of leghemoglobin, creating extremely low levels of free oxygen (nanomolar) [39]. In this way, it makes it possible for a nitrogenase to work. The level of oxygen within the nodule is closely monitored by FixL, which under virtual anaerobiosis becomes enzymatically active [35]. Thus, FixL can phosphorylate FixJ, another protein that functions as a transcription factor regulating genes involved in microaerobic respiration and the nitrogenase apparatus [35] This upstream oxygen sensor along with NifA assure that a cascade of events takes place, leading to nitrogen fixation $[35,38]$. 
FixL is a multidomain sensor protein that contains a heme $b$ group in a PAS fold domain and a histidine kinase domain in its C-terminal region (Figure 3A). Sometimes, this sensor exhibits an extra non-heme PAS domain or transmembrane segments at the $\mathrm{N}$ terminal region [5]. Despite the lack of an X-ray structure for this full-length protein, there are many structural and functional studies on this sensor that have elucidated important molecular details [40-54]. One interesting feature is the ability of this protein to recognize $\mathrm{O}_{2}$ and selectively trigger a response to the histidine kinase domain. $\mathrm{O}_{2}$ as well as $\mathrm{CO}$ and NO binds to the iron heme, where $\mathrm{O}_{2}$ has the weakest affinity of all, but at the same time it is the only one that switches off the protein enzymatic activity $[15,45]$. This is associated to its geometry upon binding and specific interactions with distal residues $[41,53,55]$. This subtle binding of $\mathrm{O}_{2}$ causes conformational changes within the heme domain, altering the heme distortion (induced planarity) and leading to specific interactions with arginine and heme propionate groups within the PAS heme domain $[41,47,53]$. These changes have been associated to the signal transduction process that propagates to the enzymatic domain. Recently, SAXS studies suggested signal transduction occurs with a more subtle movement of the domains [40], not necessarily by switching contacts. A movement of the coiled-coil linker region that connects the heme PAS and histidine kinase seems to be vital for signal transduction, affecting the proximity of the ATP binding site and the histidine phosphorylatable residue [40].

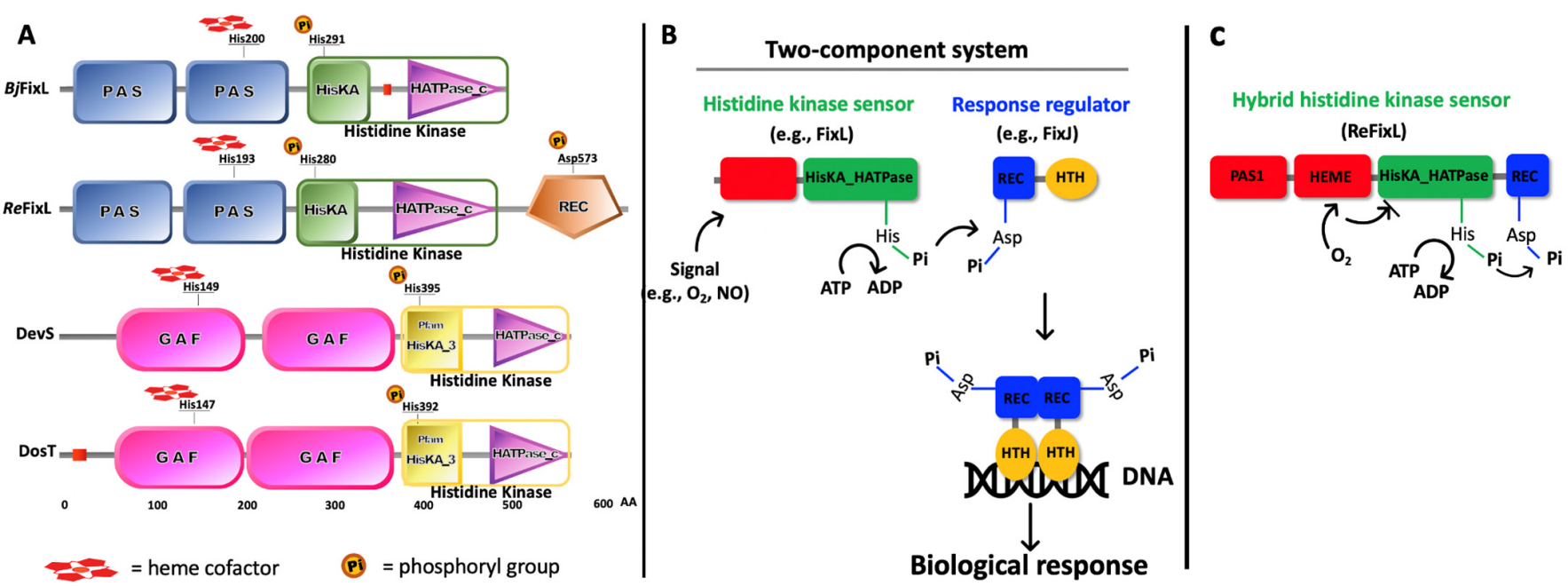

Figure 3. (A) Domain organization of FixL and DevS/DosT (heme as a red small structure, phosphorylation indicated by $\mathrm{Pi}$; heme proximal ligand and phosphorylatable residues are shown) composed of the PAS and GAF domains along with the histidine kinase domain constituted of the HisKA and HATase_c subdomains. Hybrid FixL (ReFixL) presents an additional REC domain (receiver domain) usually found at the $\mathrm{N}$-terminal region of the response regulator proteins. (B) Cartoon of the functioning of common two-component systems, where a histidine kinase sensor upon the appropriated signal becomes active, autophosphorylating a histidine residue; then, a phosphoryl group is transferred to the response regulator protein. This later becomes active upon phosphorylation and usually functions as a transcriptional factor triggering a biological response. (C) Autophosphorylation of the hybrid ReFixL, where $\mathrm{O}_{2}$ blocks histidine kinase and phosphotransferase activities. His = histidine residue, $\mathrm{Asp}=$ aspartate residue $\mathrm{AA}=$ amino acids. 
The bacteria have commonly used a particular type of sensing systems to perceive and respond to environmental changes called two-component systems, which are usually formed by one histidine kinase sensor and one response regulator protein (Figure 3B) [56]. FixL and FixJ are a typical two-component system responsible for sensing $\mathrm{O}_{2}$, where FixL is a histidine kinase sensor and FixJ is a response regulator. How these multi-domains communicate and coordinate intra- and interprotein phosphorylation are still exciting questions. The presence of additional "nonfunctional" domains in some FixL proteins raised further question on their structural roles. FixL from Bradyrhizobium japonicum (BjFixL) is such a case, where one additional non-heme PAS domain is found at the N-terminal region followed by a heme-PAS domain and a histidine kinase (Figure 3A). The actual role of this additional PAS domain is not clear, but it may be quite important as shown in another study using a hybrid FixL sensor from Rhizobium etli (ReFixL) [57]. This latter cytosolic sensor exhibits a domain organization quite similar to BjFixL (Figure 3A), but it also has an extra domain at the C-terminal region. This extra terminal domain (REC) is analogous to the receiver domain of FixJ, which contains a phosphorylatable aspartate residue (Figure 3A). Thus, this protein features as a combination of BjFixL and part of BjFixJ, being a great opportunity for questioning the function of multi-domains in the FixL-FixJ system. In such a hybrid FixL sensor, there are two phosphorylatable residues, one histidine residue centered at the kinase domain and one aspartate at the C-terminal receiver domain (Figure 3C). Then, the hybrid protein can promote histidine autophosphorylation followed by an intramolecular phosphotransfer to aspartate in the receiver domain, all within the same protein.

This hybrid ReFixL sensor brought up an opportunity to explore this cascade of phosphorylation processes and their regulation [57]. Interestingly, this sensor showed the lowest reported oxygen affinity for a heme-based gas sensor ever $\left(\mathrm{K}_{\mathrm{d}}=738 \mu \mathrm{M}\right)$ [57], despite BjFixL also having a reasonably low affinity, too $\left(\mathrm{K}_{\mathrm{d}}=140 \mu \mathrm{M}\right)$ [58]. Despite that, $R e F i x L$ exhibited very tight oxygen regulation even in the air, where only $26 \%$ of the protein is bound to oxygen. The deletion of the first PAS domain ( $\triangle \mathrm{PAS1}$ ReFixL) provoked major changes not only in the heme domain, but also in the histidine kinase activity. While the oxygen affinity increased about eightfold, the histidine kinase activity was completely turned off with minor measurable ligand regulation [57]. This lack of activity could be due to a damaged inactive histidine kinase domain; however, $\triangle \mathrm{PAS1}$ ReFixL was still capable of being phosphorylated by another fully functional ReFixL. This result supported the histidine kinase domain was still functional, but $\triangle$ PAS1 ReFixL was likely shifted toward an inactive equilibrium state. The PAS1 domain seems to allow an equilibrium between active and inactive states to be achieved, whose removal disrupted this conformational change, locking the protein in an inactive state. In another study, we also noticed the plasticity of their domains and differences in the overall stability when measured in the active versus inactive state [48]. These studies illustrated how sensitive the heme domain is and how major properties can be altered by interaction with other domains, not only by mutations within the heme domain itself. Indeed, this particular feature has been noticed by many other studies comparing heme properties of isolated heme domains with full-length proteins [1], reinforcing sensing domains are much more flexible as they should be to promote signal transduction.

Another exciting feature discovered in FixL is an $\mathrm{O}_{2}$ memory effect. This phenomenon is a hysteresis response caused upon $\mathrm{O}_{2}$ binding, which quickly inactivates histidine kinase, but FixL reactivation takes much longer once $\mathrm{O}_{2}$ dissociates [59]. There was an initial expectation that one $\mathrm{O}_{2}$ molecule bound to FixL is capable of turning off its histidine kinase activity. If this behavior was right, a linear dose response would be obtained for $\mathrm{O}_{2}$ saturation of FixL versus histidine kinase activity. However, experimental data showed the dose response for $B j F i x L$ was remarkably nonlinear, but it matched nicely the in vivo $\mathrm{O}_{2}$ dose response regulation data. In other words, this result means that a few molecules of $\mathrm{O}_{2}$ are able to inactivate many molecules of FixL due to faster $\mathrm{O}_{2}$ rebinding in comparison to slower kinetics of histidine kinase activation. This process fits well in a hysteresis model 
supporting in vitro and in vivo data. This exciting phenomenon can indeed explain how extremely low-affinity sensors work [57,59]. Actually, the nonlinear response of inhibitors (as drugs) has alerted medicinal chemists of an important aspect of association/dissociation kinetics beyond thermodynamic affinity $\left(\mathrm{K}_{\mathrm{d}}\right)$ [60]. The memory effect may explain how oxygen can regulate ReFixL so tightly despite its extremely low affinity. While this process may explain FixL behavior, it was not able to explain the nonlinear dose response for other oxygen sensors (e.g., DosP [19]), where other mechanisms may take place.

Structural changes of the heme domain of FixL were observed as reasonably fast (few microseconds) events associated with planarity/distortion of the heme and its interactions with nearby residues [61-63]. Recently, an attempt to investigate the time scale of the signal transduction process was carried out with FixL from Sinorhizobium meliloti (SmFixL) using Raman spectroscopy [64]. Despite the limitations of this study, the authors suggested conformational changes provoked in the heme domain by oxygen binding would take at least microseconds to alter the histidine kinase domain. However, it is still unknown if any further fine adjustment is required to achieve full inactivation or activation.

FixL or analogs have been found in other microorganisms, such as Caulobacter crescentus [65], Brucella abortus [66], Chlamydomonas reinhardtii [67] and Burkholderia cepacia [68,69]. This latter bacterium is part of a class of pathogens causing concerns in cystic fibrosis patients. There is growing evidence that this bacterium employs the oxygen sensor FixL to control biofilm formation, motility, intracellular invasion/persistence and virulence, opening exciting opportunities to explore this system in therapy. Beyond that, this system has also been explored in synthetic biology as mentioned later (see section "Diverse Potential Applications of Heme-Based Gas Sensors: Systems Applied in Cell Biology").

\section{DevS and DosT-A Short History}

The millenary disease, tuberculosis, is still a major global health issue, causing deaths of over 1 million people around the world [70]. The low number of drugs, emergence of multiple drug-resistant strains and the large reservoir of dormant bacteria within humans have caused a challenge to control and eradicate this disease [71,72]. Almost 20 years ago, a two(three)-component system (DevS-DevR, and later DosT) was identified in $M$. tuberculosis (Mtb) [73-75], which was associated to its virulence. Genetic studies showed this system was oxygen-responsive and associated to the initiation of the dormancy program in the bacterium $[74,76]$. The dormancy of $\mathrm{Mtb}$ is related to its persistence in humans, the lengthy medical treatment and difficulty to eradicate this disease in the world [77]. Importantly, this sensory system of DevS-DosT-DevR was shown as a suitable drug target, where two independent laboratories have been developing new compounds as novel antituberculosis drugs (see section "Diverse Potential Applications of Heme-Based Gas Sensors: Pharmacological Use").

In 2005, DevS (also known as DosS) was shown to be a GAF heme-containing protein [78] (Figure 3B). Later, DevS and its ortholog, DosT, were demonstrated to function as $\mathrm{O}_{2}$ sensors $[79,80]$, supporting previous genetic studies [74,76]. In 2007, another laboratory suggested DevS is a redox sensor while DosT is a direct oxygen sensor [81]. These apparently conflicting conclusions were addressed by other studies as discussed elsewhere [36]. In summary, there is strong and compelling evidence supporting that DevS and DosT are indeed direct oxygen sensors, including DevS having a relatively high electrochemical potential $\left(E_{\mathrm{m}}=-10 \mathrm{mV}\right.$ vs. NHE) [82]. But why nature would employ two oxygen sensors for that process? These proteins may function by sensing and responding to distinct levels of hypoxia, which would be in agreement with their oxygen affinity [79], as indicated by genetic studies [83]. DosT with a lower oxygen affinity $\left(K_{d}=26 \mu M\right)$ may perceive the initial drop in oxygen concentration, allowing initial bacterial adaptation. If this condition does not persist, it may be an easier return to normal growth; however, if a further decrease in the oxygen level takes place, then DevS becomes active, leading to major physiological changes into a dormant state. Despite their differences, the accrued biochemical knowledge on FixL-FixJ helped us to better understand this system [1,3,4]. 
Raman spectroscopy, site-direct mutagenesis and single crystal X-ray studies provided important hints on the role of key residues involved in sensing and signal transduction [84-86]. The distal ligand in the heme domain is a tyrosine residue (Y171 in DevS and Y169 in DosT), which makes a hydrogen bond with $\mathrm{O}_{2}$, supposedly assisting its binding. It is interesting to remark that such assistance was not validated for DevS, where the Y171F mutant showed an even higher affinity to oxygen [85], illustrating the complexity of these interactions. Unlike FixL, these proteins showed minor changes within the heme pocket in the active and inactive states, besides a modification in the hydrogen bonding network from the heme to the surface of the domain [86]. This effect might report $\mathrm{O}_{2}$ binding to the surface of the domain and could propagate this information into other domains as a signal transduction process. Other studies were carried out to identify the role of other residues within the heme, where arginine 204 seemed to have a critical role [87]. This residue is expected to be in a polar patch at the surface of the heme domain in an interface with the other GAF domain. Notably, the R204A mutant promoted a complete disruption in the histidine kinase activity, implicating this residue in signal transduction [87]. Earlier, another study had investigated the role of the extra GAF domain, where two constructs were compared with the wild-type one containing the two GAF domains (GAF(A)-GAF(B)) and another one with only the heme GAF domain (GAF(A)) [88]. These constructs in comparison to wild-type DevS showed distinct features by Raman spectroscopy. Interestingly, the heme GAF domain upon binding to $\mathrm{CO}$ exhibited a Raman spectrum consistent with two conformations, while the two GAF constructs had only one, indicating that the intervening domain might mediate signal transduction initiated in the heme domain.

Recently, our laboratory showed DevS is a mixture of oligomers dimer-tetrameroctamers, and more importantly, this oligomeric distribution could be shifted by selective disturbance in the heme domain [89]. Indeed, active DevS either under anaerobic (deoxyDevS) or CO-bound form (CO-DevS) exhibited a major fraction as octamers, while in the inactive state, either ferric (met-DevS) or oxygen-bound forms (oxy-DevS) showed mainly tetramers and dimers. Remarkably, the inhibition ratio (histidine kinase activity in the active/inactive states) matched nicely the relative amount of octameric/(dimeric-tetrameric) species, supporting the phenomenon of signal transduction promotes changes in the quaternary state of the protein. This process was also reasonably fast (a few minutes), and may occur in other heme-based gas sensors as well [90,91].

The overall mechanism of functioning of this two(three)-component system may be more complex than expected [25]. There is a series of other protein partners, protein modifiers (serine threonine kinase, acetylation) and cross-talks with other sensing systems involved, making this whole story complex, as discussed elsewhere [25]. Nevertheless, there are many opportunities ahead to unfold these details and find new applications for these systems either as drug targets or biological tools, etc. 


\section{Diverse Potential Applications of Heme-Based Gas Sensors}

Our understanding of the molecular functioning of heme-based gas sensors and their broad diversity has also opened new opportunities, both to develop small-molecule regulators and use them as new tools and materials, as we discuss further (Figure 4).
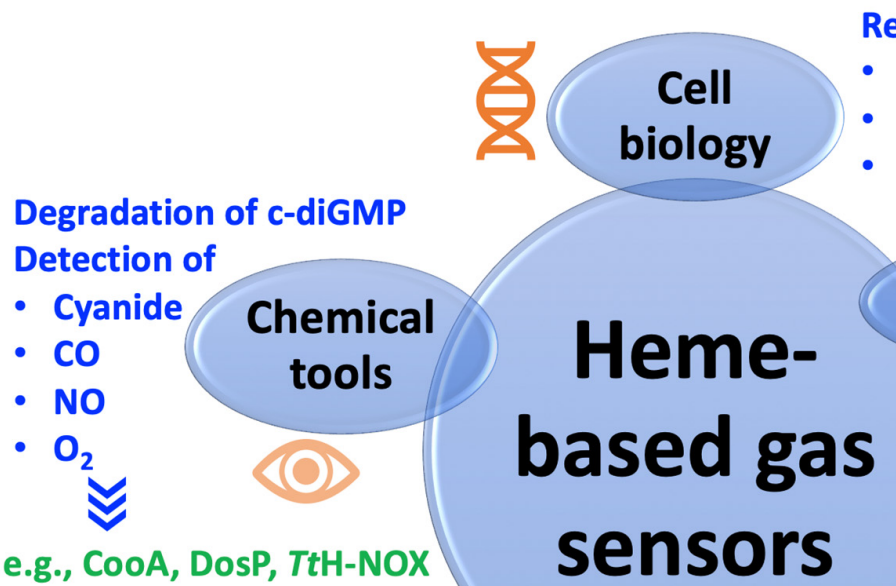

Regulation of processes

Hypoxia

Light

- $\mathrm{H}_{2}$ production
1) e.g., FixL, DosP, CooA

\section{Pharmacology}

- Riociguat

- Vericiguat

- Omniox ${ }^{\circledR}$ (artificial blood)

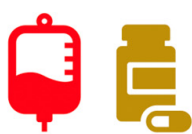

)) e.g., sGC, DevS, TtH-NOX, NosP

e.g., CooA, DosP, TtH-NOX

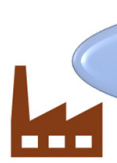

\section{Biocatalysis}

- Peroxidase $\gg$ \e.g., TtH-NOX

\section{Biochemical tools}

- $\mathrm{O}_{2}$ monitoring

- CO monitoring

- MRI reagent

- Fluorescent probes

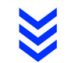

e.g., CooA, DosP, TtH-NOX

Figure 4. Chemical and biotechnological applications of heme-based gas sensors. There are five segments of investigations with some developed applications of heme-based gas sensors in cell biology (e.g., FixL was employed to achieve hypoxia and light control), pharmacology (e.g., two FDA-approved drugs are available targeting sGC, while others are under study, along with a blood substitute candidate Omniox ${ }^{\circledR}$ ), biochemical tools (e.g., CooA, DosP and TtH-NOX are explored for in vivo monitoring of $\mathrm{O}_{2}, \mathrm{CO}$ and other uses such as MRI or fluorescent reagents), biocatalysis (e.g., TtH-NOX has been explored as a peroxidase catalyst), chemical tools (e.g., CooA and Tt-HNOX have been explored for in vitro detection and measurement of cyanide, $\mathrm{CO}, \mathrm{NO}$ and $\mathrm{O}_{2}$ ).

\subsection{Pharmacological Use}

Currently, there are many heme-based gas sensors involved in key biological processes both in humans and pathogens, making them suitable drug targets for investigation [92]. Here, we described a few interesting cases, some of them still in very early stage while others with drugs approved for clinical use.

The first heme-based gas sensor discovered, sGC, has many physiological roles in humans, making it a very desirable drug target for the treatment of endothelial, cardiovascular and pulmonary disorders $[93,94]$. A series of nitric oxide (NO) donors was earlier employed targeting sGC, even before this sensor was known or this small molecule (NO) found to be biologically active. The binding of NO to sGC strongly stimulates its cyclase activity, converting GTP into cGMP [27]. This is one of the reasons for the development of NO donor molecules, which can be employed to lower blood pressure, hypertension crisis, angina pectoris, glaucoma, among other applications [94]. However, the lack of selectivity and acquired tolerance to $\mathrm{NO}$ can limit its action in continuous use. Some strategies have emerged to deal with these issues, particularly providing more selective delivery strategies either by using light, nanoparticles or other stimuli [1,94]. At the same time, other small molecules have been investigated, starting with YC-1, the first direct sGC stimulator discovered [95]. Currently, there are many organic- and inorganic-based molecules investigated as sGC stimulators or activators likely able to treat many conditions [92-94,96]. Two drugs (riociguat, 2013, and vericiguat, 2021) that function by targeting 
sGC are already approved for clinical use, opening many opportunities. Other heme-based gas sensors found in humans have also been explored as potential drug targets involved in the mood and metabolic disorders (e.g., NPAS2, Rev-erb $\alpha / \beta$ ) [92,97].

The disruption of sensing systems in bacteria has emerged as a promising strategy for the development of novel antibiotics with likely minor selective pressure [98]. Among these systems, there are heme-based gas sensor proteins as potential drug targets [1,92]. In certain cases, the use of $\mathrm{NO}$ donors can be beneficial to assist with the elimination of the bacterial infection through interaction with heme-based gas sensors [94]. One of the major obstacles to eliminate bacteria is caused by the production of biofilm that leads to antibiotic tolerance [99]. The NO sensor NosP found in P. aeruginosa and V. cholerae is involved in the regulation of biofilm production, where binding to NO promotes biofilm dispersal [100]. This has opened new opportunities for the use of NO donors, particularly in combination with antibiotics. Recently, we and others have been able to show that NO donors can function in synergy with antibiotics, promoting the disruption of biofilms and enhancement of antibiotic action [101-103].

The $\mathrm{O}_{2}$ sensor two(three)-component system of M. tuberculosis, DevS/DosT-DevR, has also become an important drug target [72,92,104]. Two laboratories have made efforts to identify new molecules to inhibit this sensing system. Tyagi's laboratory pioneered this study in identifying phenylcoumarin-based compounds through an initial in silico screening (2.5 million compounds), but their hits exhibited low biological activity [105]. Then, they carried out other studies looking at small peptides targeting DevR and DevS using the phage display technology $[106,107]$. Unfortunately, the most active peptides identified did not show suitable biological efficiency. Recently, Abramovitch's laboratory developed a cell-based phenotypic screening assay with a reporter gene under DevR regulation [108]. In this study, they employed a library of 540,288 compounds, where six classes of compounds were identified with apparent distinct mechanisms of action. These compounds showed quite promising biological activity toward Mtb with apparently distinct mechanisms of action, including a synergistic effect with anti-tuberculosis drugs (e.g., isoniazid) $[104,108,109]$. One interesting case was with artemisinin, one class of drug found in the screening, that was shown to target the heme of DevS and DosT [108]. Other laboratories had shown the potential anti-tuberculosis activity of this old compound also in combination with isoniazid (and other anti-TB drugs) [110,111], but there was no clue about its potential target. These exciting studies may continue and eventually provide a leading compound targeting dormant bacteria, a major issue during tuberculosis treatment. Besides this case, other heme-based gas sensors might function as a drug target in the development of antibiotics or antiparasitic agents, deserving a close look, including in certain FixL systems (found in the pathogens Burkholderia cepacia and Brucella abortus) $[66,68]$ ), BpeGReg (found in Bordetella pertussis, a pathogen that causes whooping cough) [112], Hpk2 (found in Treponema denticola that causes periodontal disease) [113], DosC/DosP (found in E. coli) [19,89] and HemAC-Lm (found in the parasite Leishmania) [114].

Beyond this, due to the large diversity of heme domains reported for heme-based gas sensors, they should be further investigated as potential antidotes for carbon monoxide poisoning, delivery of gasotransmitters (e.g., Sanguinate ${ }^{\circledR}[115]$ ) or even as blood substitutes as carried out with neuroglobins [116] and modified hemoglobins (e.g., Hemopure ${ }^{\circledR}$ ) [117]. There is one expired patent on the potential use of globin-based proteins including hemebased gas sensor proteins HemAT from Halobacterium salinarum and Bacillus subtilis in medicine as blood substitutes and microsensors [118]. As far as we are aware, there is only one case of a heme-based gas sensor protein being investigated as a blood substitute, which was reported for the H-NOX sensor from Thermoanaerobacter tengcongensis (TtH-NOX, Omniox ${ }^{\circledR}$ ) [119]. In this study, a modified TtH-NOX heme domain exhibited promising results in preserving myocardial contractility during acute hypoxia in an ovine model of myocardial injury, whereas NO sequestration was not an issue, commonly faced when using hemoglobin-derived biotherapeutics. This heme-based gas sensor has been explored in many other applications as described further. 


\subsection{Chemical and Biological Tools}

DosP (earlier called $E c D O S$ ) is a heme-based $\mathrm{O}_{2}$ sensor from E. coli, which upon binding to oxygen exhibits a steep increase in c-di-GMP phosphodiesterase activity [120]. This dinucleotide is an important signaling molecule in bacteria with important roles in humans as well [121]. A recent study showed that DosP can be efficiently encapsulated into mesoporous silica, where its regulated phosphodiesterase activity is reasonably preserved along with stability [120]. This type of material might have interesting chemical and biological applications. The easier chemical production of linear $\mathrm{pGpG}$ from c-di-GMP phosphodiesterase might be one potential use of this material. In addition to that, its capacity to degrade c-di-GMP might have therapeutic features against microbes that could be explored [122].

The analytical use of heme-based gas sensors as probes for diatomic gases $\left(\mathrm{O}_{2}, \mathrm{NO}\right.$ and $\mathrm{CO}$ ) or anions (cyanide) has been explored. The heme-based $\mathrm{CO}$ sensor from Rhodospirillum rubrum, CooA, was designed to report CO levels in vitro and in vivo [123]. This was achieved by fusing a fluorescent protein in the C-terminal domain, where a major conformational change occurs when CO binds. Notably, this sensor exhibited an increase in fluorescence upon binding to $\mathrm{CO}$ with a $\mathrm{K}_{\mathrm{d}}$ of $2 \mu \mathrm{M}$, which was minimally disturbed by $\mathrm{NO}, \mathrm{O}_{2}, \mathrm{H}_{2} \mathrm{~S}$, imidazole, glutathione or $\mathrm{CN}^{-}$. This probe was also investigated in vivo by transfecting HeLa cells with a probe-expressing vector, where fluorescence images were obtained either using $5 \mu \mathrm{M} \mathrm{CO}$ (externally applied) or a known CO donor molecule (CORM-2, used even at $1 \mu \mathrm{M})$.

A mutant of the H-NOX sensor from Thermoanaerobacter tengcongensis (TtH-NOX Y140F) was developed to function as an NO sensor. This mutant exhibited great properties such as no binding to oxygen, high stability to heat (up to $70^{\circ} \mathrm{C}$ ) and oxidation, but a very strong affinity to NO. Notably, this protein can be used to measure very low levels of NO even in a large background of $\mathrm{O}_{2}$. Another modification of $\mathrm{TtH}$-NOX was carried out by replacing its native heme with a ruthenium(II)-mesoporphyrin IX [124]. In this case, the protein scaffold hosted a luminescent ruthenium-based cofactor that upon binding to $\mathrm{O}_{2}$ exhibits light emission suppression, functioning as an oxygen sensor. Indeed, the authors showed they could detect up to $4.2 \mu \mathrm{M} \mathrm{O}_{2}$, claiming this is reasonably close to commercial $\mathrm{O}_{2}$ sensors [124].

In another study, meso-alkynylation of heme b cofactor was carried out, allowing further conjugation with many molecules, including fluorophores. The authors showed this modified porphyrin could be efficiently incorporated in the Tt-H-NOX protein, then labeled with an azide-based fluorophore (rhodamine) [125]. This procedure offers more flexibility where labeling is not in the protein chain, making it possible to explore fluorescence imaging as well as Raman microscopy. In a recent study, a highly fluorescent near-infrared compound, phosphorus corrole, was investigated as replacement of the native heme of the CsH-NOX sensor from Caldanaerobacter subterraneus [126] (formerly known as Thermoanaerobacter tengcongensis H-NOX or Tt-H-NOX sensor [127]). The authors showed phosphorus corrole was able to replace its native heme cofactor, providing better properties such as long wavelength emission and high quantum yield. Corrole-based compounds exhibit some structural similarity with protoporphyrin IX, but they can be much better emitters, which in combination with a robust protein scaffold can generate promising new fluorescent systems [126]. Besides these cases, this same heme-based gas sensor was also explored in other applications, such as cyanide sensor (TtH-NOX P115A mutant) [128] and MRI probes using Mn(II/III) and Gd(III) porphyrins as a substitute to the native heme [129]. 


\subsection{Systems Applied in Cell Biology}

An early study produced a sensory chimera (CskA) containing part of FixL [130], aiming mostly to understand the essential elements for building a functional sensor. These investigators combined the oxygen-sensing heme domain of SmFixL from Sinorhizobium meliloti with the histidine kinase domain of ThkA from the hyperthermophile Thermotoga maritima. In that work, two out of five constructs showed oxygen affinity close to full-length SmFixL, but none of them exhibited oxygen regulation of histidine kinase. Nonetheless, some constructs showed even higher autophosphorylation activity if compared to ThkA [130], indicating modulation of the enzymatic activity in the chimera. This frustrated attempt to prepare an oxygen-regulated system illustrated the key role of the linkers to allow proper interaction of the domains and likely allow regulation. Other attempts were more successful in achieving signal regulation as described below.

In 2008, Moffat's laboratory developed a chimeric protein by replacing the heme domain of the oxygen sensor FixL with the light-oxygen-voltage-sensing domain (LOV domain of YtvA from Bacillus subtilis) [131]. Their goal was to control reversibly the histidine kinase activity of FixL using blue light instead of oxygen. Interestingly, they prepared some protein constructs with remarkable regulation of enzymatic activity using blue light, achieving over 1000-fold inhibition. This system was also investigated in E. coli, where light irradiation was able to shut off 70-fold a gene reported based on this system [131]. This study opened exciting opportunities for a broad use of sensing systems. Another independent laboratory prepared a chimera of FixL with CckA, this latter being a histidine kinase sensor from Caulobacter crescentus, as a biological tool [132]. This system combined the sensing unit of CckA with the histidine kinase of FixL and full-length FixJ along with a fluorescent gene reporter responsive to phosphorylated FixJ. The use of this biological tool allowed them to better understand the molecular signaling mechanism associated with the asymmetric cell division of $C$. crescentus [132].

Another chimeric protein was developed using the heme PAS domain of DosP, an oxygen sensor in E. coli, combined with a yellow fluorescent protein (Venus YFP) [133]. This new protein, called ANA-Y (anaerobic/aerobic sensing yellow fluorescence protein), has a coiled-coil linker optimized to provide suitable fluorescence response upon oxygen binding to the heme domain. This system can report oxygen concentrations in the micromolar range, which was employed as a genetic probe in synthetic biology to monitor initial photosynthetic production of oxygen in cyanobacteria [133]. In the previous subsection (see "Diverse Potential Applications of Heme-Based Gas Sensors: Chemical and Biological Tools"), we also presented a CO probe based on a chimeric protein of CooA. This sensor regulates bacterial processes involving the consumption of $\mathrm{CO}$ with the generation of $\mathrm{H}_{2}$ such as in the water-gas shift reaction $\left(\mathrm{CO}+\mathrm{H}_{2} \mathrm{O} \rightarrow \mathrm{CO}_{2}+\mathrm{H}_{2}\right)$. This process is catalyzed by two enzymes, carbon monoxide dehydrogenase (CODH) and carbon monoxide-dependent hydrogenase (CO-Hyd) under regulation by CooA [134]. Aiming to enhance the production of $\mathrm{H}_{2}$ by Citrobacter amalonaticus Y19, an engineered strain was prepared containing a plasmid carrying the cooA gene for overexpression [134]. This genetic alteration promoted an expressive increase in $\mathrm{H}_{2}$ production (3.4-fold) by this bacterium, supporting this type of biotechnological strategy. 


\subsection{Biocatalysts}

In 2018, Dr Frances Arnold was awarded a Nobel Prize in Chemistry for her contribution to the development of novel biocatalysts based on directed evolution [135]. Despite that, biocatalysts have been developed not only based on directed evolution (random mutations), but also with exchange of metal ions and incorporation of new cofactors that have broadened our horizon. Indeed, enzymatic catalysis of reactions not reported to be carried out by nature were developed by designing novel biocatalysts. Myoglobin, a non-enzymatic hemeprotein, has been widely explored and converted into an outstanding novel catalyst for many distinct biological and nonbiological reactions, as reviewed elsewhere [136]. The same has been carried out for many other metalloproteins, including other hemeproteins (e.g., cytochrome c, cytochrome P450). This may be a great opportunity to explore many distinct heme domains found in the families of heme-based gas sensors. As far as we are aware, there is only one case explored so far, as described below.

Aiming to explore and enhance potential catalytic properties of the heme-based gas sensor Tt-H-NOX, its heme domain was studied and subjected to site-direct mutagenesis at the distal tyrosine ligand [137]. Interestingly, this protein showed capacity to decompose $\mathrm{H}_{2} \mathrm{O}_{2}$, which was strongly enhanced in the $\mathrm{Y} 140 \mathrm{H}$ mutant and lowered in the Y140A mutant. Their peroxidase activities were investigated using the ABTS (2,2'-azino-bis(3ethylbenzothiazoline-6-sulphonic acid)) substrate along with $\mathrm{H}_{2} \mathrm{O}_{2}$, where the WT protein showed moderate activity but the $\mathrm{Y} 140 \mathrm{H}$ mutant was significantly better $(70 \%$ higher) in degrading ABTS. Despite this protein showed a much lower turnover compared to other known catalytic proteins, the authors claimed there is a comparable efficiency in oxidizing substrates as in some native catalysts (e.g., but using different substrates, $\mathrm{TtH}$ NOX $k_{\text {cat }}=0.06 \mathrm{~s}^{-1}$ for ABTS versus cytochrome P450BM-3 $\mathrm{k}_{\text {cat }}<0.008 \mathrm{~s}^{-1}$ ) [137]. This study did not provide appealing catalytical results, but it highlighted the opportunities ahead, taking advantage of the thermostability, easy production and structural robustness of that heme-based gas sensor protein.

In another study, a multidomain protein containing one heme PAS domain showed an unexpected oxidative N-demethylase activity based on the heme cofactor [138]. The PAS domain is indeed a typical signal transduction unit employed by many types of sensors, including heme-based gas sensors, which has never exhibited any reported catalytic activity. Despite this protein might not be a true heme-based gas sensor, it has exposed the heme PAS domain as a biocatalytic unit deserving further studies. This unique case highlights the broad opportunities to explore biocatalysis using many other types of heme domains from heme-based gas sensors.

As shown here, there are many opportunities to create novel tools and materials by manipulating heme domains. One strategy to explore this is to replace the native heme by another metalloporphyrin analogs, providing novel functions to the protein as described before. To achieve this, engineered E. coli strains or growth conditions have been explored to facilitate direct incorporation of heme analogs or production of hemeless proteins [139-142]. The engineered RP523 strain of E. coli was prepared, exhibiting disruption of biosynthesis of the heme (hemB and hemC) along with the heme permeability phenotype [139]. This feature allowed direct incorporation of metalloporphyrins once they were provided in the cell culture medium [139], but oxygen sensitivity and the toxicity of cofactors are a concern for its success. Another strategy was to use an E. coli BL21(DE3) strain containing a plasmid bearing the heme transporter $\mathrm{ChuA}$ allowing the uptake of heme analogs provided in the cell medium [141]. In addition to that, E. coli was grown in an iron-depleted medium to minimize heme biosynthesis, but up to $5 \%$ of the protein could still bear the heme. Alternatively, it was shown that the hemeproteins overexpressed in E. coli BL21(DE3) employing the M9 medium are mainly hemeless, where the incorporation of exogenous metalloporphyrins can be easily achieved by mixing with lysed cells [140]. These approaches are important technical advances helping the success of using heme-based proteins. 


\section{Final Considerations}

Heme-based gas sensor proteins are a remarkable widespread superfamily of sensing systems. These moderately old sensors always surprise us with their diversity, appearance of new families and mechanisms of action. There is no doubt many more are still going to be discovered. The multiple applications of these systems are just unfolding, covering biological and chemical tools, biocatalysis and drug targets, making them a hot spot of opportunities much beyond our necessity of understanding their molecular functioning.

Author Contributions: Conceptualization E.H.S.S.; Writing—original draft preparation: E.H.S.S.; Writing-review and editing: A.C.S.G., W.G.G. and E.H.S.S.; Project administration: E.H.S.S.; Supervision E.H.S.S.; Visualization: A.C.S.G., W.G.G. and E.H.S.S. All authors have read and agreed to the published version of the manuscript.

Funding: This work was funded by CNPq (EHSS 308383/2018-4), the National Institute of Science and Technology on Tuberculosis (INCT-TB, financed by CNPq/FAPERGS/CAPES/BNDES) and Coordenação de Aperfeiçoamento de Pessoal de Nível Superior-Brasil (CAPES), Finance Code 001 (PROEX 23038.000509/2020-82).

Institutional Review Board Statement: Not applicable.

Informed Consent Statement: Not applicable.

Acknowledgments: We wish to thank all the organizers of XXI SPB National Congress of Biochemistry 2021 that took place in Évora (Portugal) for the high-quality meeting and the opportunity to deliver a talk on heme-based gas sensors and also contribute to this special issue. We are also thankful to CNPq (EHSS 308383/2018-4) and the National Institute of Science and Technology on Tuberculosis (INCT-TB, financed by CNPq/FAPERGS/CAPES/BNDES) for financial support. This study was also financed in part by Coordenação de Aperfeiçoamento de Pessoal de Nível Superior-Brasil (CAPES), Finance Code 001 (PROEX 23038.000509/2020-82).

Conflicts of Interest: The authors declare no conflict of interest.

\begin{tabular}{|c|c|}
\hline BpeGReg & Bordetella pertussis globin-coupled regulator \\
\hline CckA & Caulobacter crescentus histidine kinase protein A \\
\hline c-di-GMP & Cyclic dimeric $\left(3^{\prime}, 5^{\prime}\right)$ guanosine monophosphate \\
\hline cGMP & Cyclic guanosine monophosphate \\
\hline CsH-NOX & H-NOX sensor from Caldanaerobacter subterraneus, formerly known as TtH-NOX \\
\hline CskA & Chimeric sensory kinase A \\
\hline CooA & CO oxidation activator protein \\
\hline CORM-2 & CO-releasing molecule 2 \\
\hline DevS & Differentially expressed in virulent strain sensor protein, the same protein as DosS \\
\hline DevR & $\begin{array}{l}\text { Differentially expressed in virulent strain response regulator protein, the same } \\
\text { protein as DosR }\end{array}$ \\
\hline DosC & Direct oxygen sensor cyclase protein \\
\hline DosP & Direct oxygen sensor phosphodiesterase protein \\
\hline DosS & Dormancy survival sensor protein \\
\hline DosT & Dormancy survival sensor T protein \\
\hline EcDOS & Escherichia coli direct oxygen sensor protein, the same protein as DosP \\
\hline FIST & F-box and intracellular signal transduction proteins domain \\
\hline FixL & Rhizobial nitrogen fixation gene L protein \\
\hline FixJ & Nitrogen fixation gene J protein \\
\hline FNR & Fumarate and nitrate reduction protein \\
\hline GAF & cGMP-specific phosphodiesterases, adenylyl cyclase, and FhlA proteins domain \\
\hline
\end{tabular}




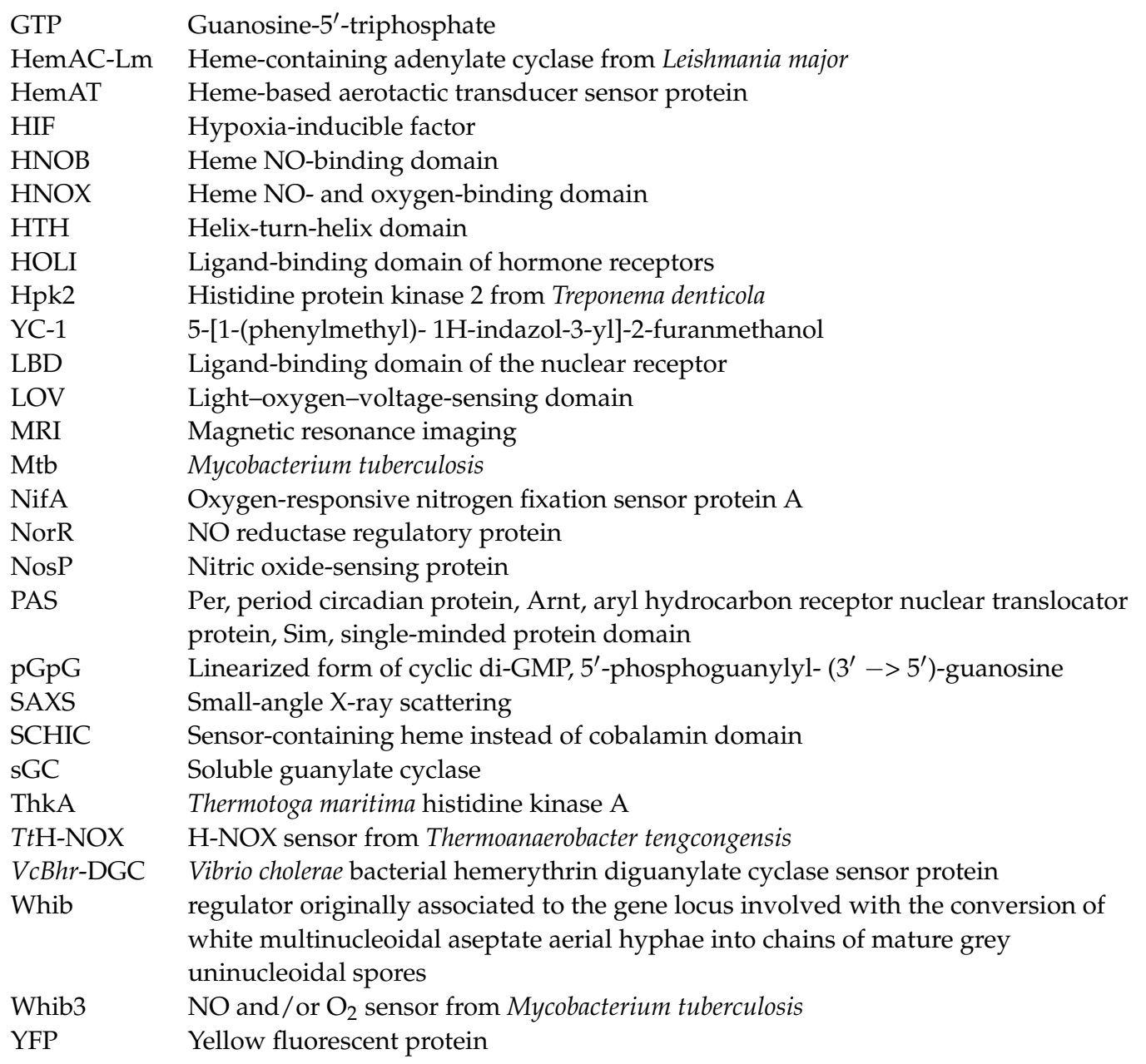

\section{References}

1. Gonzaga de França Lopes, L.; Gouveia Júnior, F.S.; Karine Medeiros Holanda, A.; Maria Moreira de Carvalho, I.; Longhinotti, E.; Paulo, T.F.; Abreu, D.S.; Bernhardt, P.V.; Gilles-Gonzalez, M.-A.; Cirino Nogueira Diógenes, I.; et al. Bioinorganic systems responsive to the diatomic gases $\mathrm{O}_{2}, \mathrm{NO}$, and $\mathrm{CO}$ : From biological sensors to therapy. Coord. Chem. Rev. 2021, 445, 214096. [CrossRef]

2. Negrerie, M. Iron transitions during activation of allosteric heme proteins in cell signaling. Metallomics 2019, 11, 868-893. [CrossRef]

3. Gilles-Gonzalez, M.A.; Gonzalez, G. Heme-based sensors: Defining characteristics, recent developments, and regulatory hypotheses. J. Inorg. Biochem. 2005, 99, 1-22. [CrossRef] [PubMed]

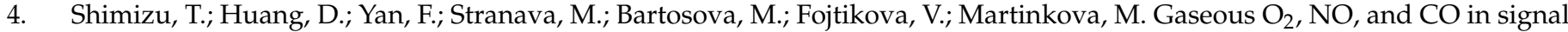
transduction: Structure and function relationships of heme-based gas sensors and heme-redox sensors. Chem. Rev. 2015, 115, 6491-6533. [CrossRef] [PubMed]

5. Gilles-Gonzalez, M.-A.; Gonzalez, G. A Surfeit of Biological Heme-based Sensors. In The Smallest Biomolecules: Diatomics and Their Interactions with Heme Proteins; Ghosh, A., Ed.; Elsevier: Amsterdam, The Netherlands, 2008.

6. Britt, R.D.; Rao, G.; Tao, L. Bioassembly of complex iron-sulfur enzymes: Hydrogenases and nitrogenases. Nat. Rev. Chem. 2020, 4, 542-549. [CrossRef] [PubMed]

7. D'Autreaux, B.; Tucker, N.P.; Dixon, R.; Spiro, S. A non-haem iron centre in the transcription factor NorR senses nitric oxide. Nature 2005, 437, 769-772. [CrossRef]

8. Schaller, R.A.; Ali, S.K.; Klose, K.E.; Kurtz, D.M., Jr. A bacterial hemerythrin domain regulates the activity of a Vibrio cholerae diguanylate cyclase. Biochemistry 2012, 51, 8563-8570. [CrossRef]

9. Crack, J.C.; Green, J.; Thomson, A.J.; Le Brun, N.E. Iron-sulfur clusters as biological sensors: The chemistry of reactions with molecular oxygen and nitric oxide. Acc. Chem. Res. 2014, 47, 3196-3205. [CrossRef]

10. Gilles-Gonzalez, M.A.; Ditta, G.S.; Helinski, D.R. A haemoprotein with kinase activity encoded by the oxygen sensor of Rhizobium meliloti. Nature 1991, 350, 170-172. [CrossRef] 
11. Hossain, S.; Boon, E.M. Discovery of a Novel Nitric Oxide Binding Protein and Nitric-Oxide-Responsive Signaling Pathway in Pseudomonas aeruginosa. ACS Infect. Dis. 2017, 3, 454-461. [CrossRef]

12. Taabazuing, C.Y.; Hangasky, J.A.; Knapp, M.J. Oxygen sensing strategies in mammals and bacteria. J. Inorg. Biochem. 2014, 133, 63-72. [CrossRef]

13. Fandrey, J.; Schodel, J.; Eckardt, K.U.; Katschinski, D.M.; Wenger, R.H. Now a Nobel gas: Oxygen. Pflug. Arch. 2019, 471, 1343-1358. [CrossRef] [PubMed]

14. Crack, J.C.; Thomson, A.J.; Le Brun, N.E. Mass spectrometric identification of intermediates in the $\mathrm{O}_{2}$-driven [4Fe-4S] to [2Fe-2S] cluster conversion in FNR. Proc. Natl. Acad. Sci. USA 2017, 114, E3215-E3223. [CrossRef] [PubMed]

15. Gilles-Gonzalez, M.A.; Gonzalez, G.; Sousa, E.H.; Tuckerman, J. Oxygen-sensing histidine-protein kinases: Assays of ligand binding and turnover of response-regulator substrates. Methods Enzymol. 2008, 437, 173-189. [CrossRef]

16. Fojtikova, V.; Stranava, M.; Vos, M.H.; Liebl, U.; Hranicek, J.; Kitanishi, K.; Shimizu, T.; Martinkova, M. Kinetic Analysis of a Globin-Coupled Histidine Kinase, AfGcHK: Effects of the Heme Iron Complex, Response Regulator, and Metal Cations on Autophosphorylation Activity. Biochemistry 2015, 54, 5017-5029. [CrossRef] [PubMed]

17. Arnold, W.P.; Mittal, C.K.; Katsuki, S.; Murad, F. Nitric oxide activates guanylate cyclase and increases guanosine $3^{\prime}: 5^{\prime}$-cyclic monophosphate levels in various tissue preparations. Proc. Natl. Acad. Sci. USA 1977, 74, 3203-3207. [CrossRef]

18. Patterson, D.C.; Ruiz, M.P.; Yoon, H.; Walker, J.A.; Armache, J.P.; Yennawar, N.H.; Weinert, E.E. Differential ligand-selective control of opposing enzymatic activities within a bifunctional c-di-GMP enzyme. Proc. Natl. Acad. Sci. USA 2021, 118, e2100657118 [CrossRef] [PubMed]

19. Tuckerman, J.R.; Gonzalez, G.; Sousa, E.H.; Wan, X.; Saito, J.A.; Alam, M.; Gilles-Gonzalez, M.A. An oxygen-sensing diguanylate cyclase and phosphodiesterase couple for c-di-GMP control. Biochemistry 2009, 48, 9764-9774. [CrossRef]

20. Shimizu, T.; Lengalova, A.; Martinek, V.; Martinkova, M. Heme: Emergent roles of heme in signal transduction, functional regulation and as catalytic centres. Chem. Soc. Rev. 2019, 48, 5624-5657. [CrossRef]

21. Gilles-Gonzalez, M.A.; Sousa, E.H.S. Escherichia coli DosC and DosP: A role of c-di-GMP in compartmentalized sensing by degradosomes. Adv. Microb. Physiol. 2019, 75, 53-67. [CrossRef]

22. Tuckerman, J.R.; Gonzalez, G.; Gilles-Gonzalez, M.A. Cyclic di-GMP activation of polynucleotide phosphorylase signal-dependent RNA processing. J. Mol. Biol. 2011, 407, 633-639. [CrossRef]

23. Shelver, D.; Kerby, R.L.; He, Y.; Roberts, G.P. CooA, a CO-sensing transcription factor from Rhodospirillum rubrum, is a CO-binding heme protein. Proc. Natl. Acad. Sci. USA 1997, 94, 11216-11220. [CrossRef]

24. Schofield, C.J.; Ratcliffe, P.J. Oxygen sensing by HIF hydroxylases. Nat. Rev. Mol. Cell Biol. 2004, 5, 343-354. [CrossRef]

25. Nunes, E.D.; Villela, A.D.; Basso, L.A.; Teixeira, E.H.; Andrade, A.L.; Vasconcelos, M.A.; Neto, L.G.D.; Gondim, A.C.S.; Diogenes, I.C.N.; Romo, A.I.B.; et al. Light-induced disruption of an acyl hydrazone link as a novel strategy for drug release and activation: Isoniazid as a proof-of-concept case. Inorg. Chem. Front. 2020, 7, 859-870. [CrossRef]

26. Kang, Y.; Liu, R.; Wu, J.X.; Chen, L. Structural insights into the mechanism of human soluble guanylate cyclase. Nature 2019, 574, 206-210. [CrossRef]

27. Wittenborn, E.C.; Marletta, M.A. Structural Perspectives on the Mechanism of Soluble Guanylate Cyclase Activation. Int. J. Mol. Sci. 2021, 22, 5439. [CrossRef]

28. Horst, B.G.; Yokom, A.L.; Rosenberg, D.J.; Morris, K.L.; Hammel, M.; Hurley, J.H.; Marletta, M.A. Allosteric activation of the nitric oxide receptor soluble guanylate cyclase mapped by cryo-electron microscopy. Elife 2019, 8, e50634. [CrossRef]

29. Lanzilotta, W.N.; Schuller, D.J.; Thorsteinsson, M.V.; Kerby, R.L.; Roberts, G.P.; Poulos, T.L. Structure of the CO sensing transcription activator CooA. Nat. Struct. Biol. 2000, 7, 876-880. [CrossRef]

30. Williams, D.E.; Nisbett, L.M.; Bacon, B.; Boon, E. Bacterial Heme-Based Sensors of Nitric Oxide. Antioxid. Redox Signal. 2018, 29, 1872-1887. [CrossRef]

31. Stuehr, D.J.; Misra, S.; Dai, Y.; Ghosh, A. Maturation, inactivation, and recovery mechanisms of soluble guanylyl cyclase. J. Biol. Chem. 2021, 296, 100336. [CrossRef]

32. Friebe, A.; Sandner, P.; Schmidtko, A. cGMP: A unique 2nd messenger molecule-Recent developments in cGMP research and development. Naunyn-Schmiedebergs Arch. Pharmacol. 2020, 393, 287-302. [CrossRef]

33. Sousa, E.H.S.; Gonzalez, G.; Gilles-Gonzalez, M.A. Soluble guanylate cyclase and its microbial relatives. In The Smallest Biomolecules: Perspectives on Heme-Diatomic Interactions; Ghosh, A., Ed.; Elsevier: Amsterdam, The Netherlands, 2008; pp. 524-539.

34. Bian, K.; Murad, F. What is next in nitric oxide research? From cardiovascular system to cancer biology. Nitric Oxide 2014, 43, 3-7. [CrossRef]

35. Rutten, P.J.; Poole, P.S. Oxygen regulatory mechanisms of nitrogen fixation in rhizobia. Adv. Microb. Physiol. 2019, 75, 325-389. [CrossRef]

36. Sousa, E.H.S.; Gilles-Gonzalez, M.A. Haem-Based Sensors of O2: Lessons and Perspectives. Adv. Microb. Physiol. 2017, 71, 235-257. [CrossRef]

37. Ganesh, I.; Gwon, D.A.; Lee, J.W. Gas-Sensing Transcriptional Regulators. Biotechnol. J. 2020, 15, e1900345. [CrossRef]

38. Dixon, R.; Kahn, D. Genetic regulation of biological nitrogen fixation. Nat. Rev. Microbiol. 2004, 2, 621-631. [CrossRef]

39. Ledermann, R.; Schulte, C.C.M.; Poole, P.S. How Rhizobia Adapt to the Nodule Environment. J. Bacteriol. 2021, 203 , e0053920. [CrossRef] 
40. Wright, G.S.A.; Saeki, A.; Hikima, T.; Nishizono, Y.; Hisano, T.; Kamaya, M.; Nukina, K.; Nishitani, H.; Nakamura, H.; Yamamoto, M.; et al. Architecture of the complete oxygen-sensing FixL-FixJ two-component signal transduction system. Sci. Signal. 2018, 11. [CrossRef]

41. Gilles-Gonzalez, M.A.; Caceres, A.I.; Sousa, E.H.; Tomchick, D.R.; Brautigam, C.; Gonzalez, C.; Machius, M. A proximal arginine R206 participates in switching of the Bradyrhizobium japonicum FixL oxygen sensor. J. Mol. Biol. 2006, 360, 80-89. [CrossRef]

42. Balland, V.; Bouzhir-Sima, L.; Anxolabéhère-Mallart, E.; Boussac, A.; Vos, M.H.; Liebl, U.; Mattioli, T.A. Functional Implications of the Propionate 7-Arginine 220 Interaction in the FixLH Oxygen Sensor from Bradyrhizobium japonicum. Biochemistry 2006, 45, 2072-2084. [CrossRef]

43. Sousa, E.H.; Gonzalez, G.; Gilles-Gonzalez, M.A. Oxygen blocks the reaction of the FixL-FixJ complex with ATP but does not influence binding of FixJ or ATP to FixL. Biochemistry 2005, 44, 15359-15365. [CrossRef]

44. Key, J.; Moffat, K. Crystal structures of deoxy and CO-bound bjFixLH reveal details of ligand recognition and signaling Biochemistry 2005, 44, 4627-4635. [CrossRef]

45. Tuckerman, J.R.; Gonzalez, G.; Dioum, E.M.; Gilles-Gonzalez, M.A. Ligand and oxidation-state specific regulation of the heme-based oxygen sensor FixL from Sinorhizobium meliloti. Biochemistry 2002, 41, 6170-6177. [CrossRef]

46. Hao, B.; Isaza, C.; Arndt, J.; Soltis, M.; Chan, M.K. Structure-based mechanism of O2 sensing and ligand discrimination by the FixL heme domain of Bradyrhizobium japonicum. Biochemistry 2002, 41, 12952-12958. [CrossRef]

47. Gong, W.; Hao, B.; Mansy, S.S.; Gonzalez, G.; Gilles-Gonzalez, M.A.; Chan, M.K. Structure of a biological oxygen sensor: A new mechanism for heme-driven signal transduction. Proc. Natl. Acad. Sci. USA 1998, 95, 15177-15182. [CrossRef]

48. Guimaraes, W.G.; Gondim, A.C.S.; Costa, P.; Gilles-Gonzalez, M.A.; Lopes, L.G.F.; Carepo, M.S.P.; Sousa, E.H.S. Insights into signal transduction by a hybrid FixL: Denaturation study of on and off states of a multi-domain oxygen sensor. J. Inorg. Biochem. 2017, 172, 129-137. [CrossRef]

49. Honorio-Felicio, N.; Carepo, M.S.; Paulo, T.D.F.; de Franca Lopes, L.G.; Sousa, E.H.; Diogenes, I.C.; Bernhardt, P.V. The HemeBased Oxygen Sensor Rhizobium etli FixL: Influence of Auxiliary Ligands on Heme Redox Potential and Implications on the Enzyme Activity. J. Inorg. Biochem. 2016, 164, 34-41. [CrossRef]

50. Yamawaki, T.; Ishikawa, H.; Mizuno, M.; Nakamura, H.; Shiro, Y.; Mizutani, Y. Regulatory Implications of Structural Changes in Tyr201 of the Oxygen Sensor Protein FixL. Biochemistry 2016, 55, 4027-4035. [CrossRef]

51. Yamada, S.; Sugimoto, H.; Kobayashi, M.; Ohno, A.; Nakamura, H.; Shiro, Y. Structure of PAS-linked histidine kinase and the response regulator complex. Structure 2009, 17, 1333-1344. [CrossRef]

52. Miksovska, J.; Suquet, C.; Satterlee, J.D.; Larsen, R.W. Characterization of conformational changes coupled to ligand photodissociation from the heme binding domain of FixL. Biochemistry 2005, 44, 10028-10036. [CrossRef]

53. Dunham, C.M.; Dioum, E.M.; Tuckerman, J.R.; Gonzalez, G.; Scott, W.G.; Gilles-Gonzalez, M.A. A distal arginine in oxygensensing heme-PAS domains is essential to ligand binding, signal transduction, and structure. Biochemistry 2003, 42, 7701-7708. [CrossRef]

54. Miyatake, H.; Mukai, M.; Adachi, S.; Nakamura, H.; Tamura, K.; Iizuka, T.; Shiro, Y.; Strange, R.W.; Hasnain, S.S. Iron coordination structures of oxygen sensor FixL characterized by Fe K-edge extended X-ray absorption fine structure and resonance raman spectroscopy. J. Biol. Chem. 1999, 274, 23176-23184. [CrossRef]

55. Gong, W.; Hao, B.; Chan, M.K. New mechanistic insights from structural studies of the oxygen-sensing domain of Bradyrhizobium japonicum FixL. Biochemistry 2000, 39, 3955-3962. [CrossRef] [PubMed]

56. Capra, E.J.; Laub, M.T. Evolution of two-component signal transduction systems. Annu. Rev. Microbiol. 2012, 66, 325-347. [CrossRef] [PubMed]

57. Sousa, E.H.; Tuckerman, J.R.; Gondim, A.C.; Gonzalez, G.; Gilles-Gonzalez, M.A. Signal transduction and phosphoryl transfer by a FixL hybrid kinase with low oxygen affinity: Importance of the vicinal PAS domain and receiver aspartate. Biochemistry 2013, 52, 456-465. [CrossRef]

58. Gilles-Gonzalez, M.A.; Gonzalez, G.; Perutz, M.F.; Kiger, L.; Marden, M.C.; Poyart, C. Heme-based sensors, exemplified by the kinase FixL, are a new class of heme protein with distinctive ligand binding and autoxidation. Biochemistry 1994, 33, 8067-8073. [CrossRef]

59. Sousa, E.H.; Tuckerman, J.R.; Gonzalez, G.; Gilles-Gonzalez, M.A. A memory of oxygen binding explains the dose response of the heme-based sensor FixL. Biochemistry 2007, 46, 6249-6257. [CrossRef]

60. Vauquelin, G.; Charlton, S.J. Long-lasting target binding and rebinding as mechanisms to prolong in vivo drug action. Br. J. Pharmacol. 2010, 161, 488-508. [CrossRef]

61. Nuernberger, P.; Lee, K.F.; Bonvalet, A.; Bouzhir-Sima, L.; Lambry, J.C.; Liebl, U.; Joffre, M.; Vos, M.H. Strong ligand-protein interactions revealed by ultrafast infrared spectroscopy of $\mathrm{CO}$ in the heme pocket of the oxygen sensor FixL. J. Am. Chem. Soc. 2011, 133, 17110-17113. [CrossRef] [PubMed]

62. Key, J.; Srajer, V.; Pahl, R.; Moffat, K. Time-resolved crystallographic studies of the heme domain of the oxygen sensor FixL: Structural dynamics of ligand rebinding and their relation to signal transduction. Biochemistry 2007, 46, 4706-4715. [CrossRef]

63. Yano, S.; Ishikawa, H.; Mizuno, M.; Nakamura, H.; Shiro, Y.; Mizutani, Y. Ultraviolet resonance Raman observations of the structural dynamics of rhizobial oxygen sensor FixL on ligand recognition. J. Phys. Chem. B 2013, 117, 15786-15791. [CrossRef]

64. Yamawaki, T.; Mizuno, M.; Ishikawa, H.; Takemura, K.; Kitao, A.; Shiro, Y.; Mizutani, Y. Regulatory Switching by Concerted Motions on the Microsecond Time Scale of the Oxygen Sensor Protein FixL. J. Phys. Chem. B 2021. [CrossRef] 
65. Crosson, S.; McGrath, P.T.; Stephens, C.; McAdams, H.H.; Shapiro, L. Conserved modular design of an oxygen sensory/signaling network with species-specific output. Proc. Natl. Acad. Sci. USA 2005, 102, 8018-8023. [CrossRef] [PubMed]

66. Roset, M.S.; Almiron, M.A. FixL-like sensor FlbS of Brucella abortus binds haem and is necessary for survival within eukaryotic cells. FEBS Lett. 2013, 587, 3102-3107. [CrossRef] [PubMed]

67. Murthy, U.M.; Wecker, M.S.; Posewitz, M.C.; Gilles-Gonzalez, M.A.; Ghirardi, M.L. Novel FixL homologues in Chlamydomonas reinhardtii bind heme and $\mathrm{O}(2)$. FEBS Lett. 2012, 586, 4282-4288. [CrossRef]

68. Schaefers, M.M.; Liao, T.L.; Boisvert, N.M.; Roux, D.; Yoder-Himes, D.; Priebe, G.P. An Oxygen-Sensing Two-Component System in the Burkholderia cepacia Complex Regulates Biofilm, Intracellular Invasion, and Pathogenicity. PLoS Pathog. 2017, 13, e1006116. [CrossRef] [PubMed]

69. Schaefers, M.M.; Wang, B.X.; Boisvert, N.M.; Martini, S.J.; Bonney, S.L.; Marshall, C.W.; Laub, M.T.; Cooper, V.S.; Priebe, G.P. Evolution towards Virulence in a Burkholderia Two-Component System. MBio 2021, 12, e0182321. [CrossRef] [PubMed]

70. WHO. Global Tuberculosis Report; World Health Organization: Geneva, Switzerland, 2020.

71. Campanico, A.; Harjivan, S.G.; Warner, D.F.; Moreira, R.; Lopes, F. Addressing Latent Tuberculosis: New Advances in Mimicking the Disease, Discovering Key Targets, and Designing Hit Compounds. Int. J. Mol. Sci. 2020, 21, 8854. [CrossRef] [PubMed]

72. Sousa, E.H.S.; Diogenes, I.C.N.; Lopes, L.G.F.; Moura, J.J.G. Potential therapeutic approaches for a sleeping pathogen: Tuberculosis a case for bioinorganic chemistry. J. Biol. Inorg. Chem. 2020, 25, 685-704. [CrossRef]

73. Dasgupta, N.; Kapur, V.; Singh, K.K.; Das, T.K.; Sachdeva, S.; Jyothisri, K.; Tyagi, J.S. Characterization of a two-component system, devR-devS, of Mycobacterium tuberculosis. Tuber. Lung Dis. 2000, 80, 141-159. [CrossRef]

74. Saini, D.K.; Malhotra, V.; Dey, D.; Pant, N.; Das, T.K.; Tyagi, J.S. DevR-DevS is a bona fide two-component system of Mycobacterium tuberculosis that is hypoxia-responsive in the absence of the DNA-binding domain of DevR. Microbiology 2004, 150, 865-875. [CrossRef] [PubMed]

75. Saini, D.K.; Malhotra, V.; Tyagi, J.S. Cross talk between DevS sensor kinase homologue, Rv2027c, and DevR response regulator of Mycobacterium tuberculosis. FEBS Lett. 2004, 565, 75-80. [CrossRef] [PubMed]

76. Roberts, D.M.; Liao, R.P.; Wisedchaisri, G.; Hol, W.G.; Sherman, D.R. Two sensor kinases contribute to the hypoxic response of Mycobacterium tuberculosis. J. Biol. Chem. 2004, 279, 23082-23087. [CrossRef]

77. Gupta, V.K.; Kumar, M.M.; Singh, D.; Bisht, D.; Sharma, S. Drug targets in dormant Mycobacterium tuberculosis: Can the conquest against tuberculosis become a reality? Infect. Dis. 2018, 50, 81-94. [CrossRef]

78. Sardiwal, S.; Kendall, S.L.; Movahedzadeh, F.; Rison, S.C.; Stoker, N.G.; Djordjevic, S. A GAF domain in the hypoxia/NO-inducible Mycobacterium tuberculosis DosS protein binds haem. J. Mol. Biol. 2005, 353, 929-936. [CrossRef] [PubMed]

79. Sousa, E.H.S.; Tuckerman, J.R.; Gonzalez, G.; Gilles-Gonzalez, M.-A. DosT and DevS are oxygen-switched kinases in Mycobacterium tuberculosis. Protein Sci. 2007, 16, 1708-1719. [CrossRef]

80. Sousa, E.H.S.; Gonzalez, G.; Gilles-Gonzalez, M.A. Target DNA stabilizes Mycobacterium tuberculosis DevR/DosR phosphorylation by the full-length oxygen sensors DevS/DosS and DosT. FEBS J. 2017, 284, 3954-3967. [CrossRef]

81. Kumar, A.; Toledo, J.C.; Patel, R.P.; Lancaster, J.R.; Steyn, A.J.C. Mycobacterium tuberculosis DosS is a redox sensor and DosT is a hypoxia sensor. Proc. Natl. Acad. Sci. USA 2007, 104, 11568-11573. [CrossRef] [PubMed]

82. Barreto, G.A.; Carepo, M.S.P.; Gondim, A.C.S.; Guimarães, W.G.; Lopes, L.G.F.; Bernhardt, P.V.; Paulo, T.F.; Sousa, E.H.S.; Diógenes, I.C.N. A spectroelectrochemical investigation of the heme-based sensor DevS from Mycobacterium tuberculosis: A redox versus oxygen sensor. FEBS J. 2019, 286, 4278-4293. [CrossRef]

83. Honaker, R.W.; Leistikow, R.L.; Bartek, I.L.; Voskuil, M.I. Unique roles of DosT and DosS in DosR regulon induction and Mycobacterium tuberculosis dormancy. Infect. Immun. 2009, 77, 3258-3263. [CrossRef]

84. Cho, H.Y.; Cho, H.J.; Kim, Y.M.; Oh, J.I.; Kang, B.S. Structural insight into the heme-based redox sensing by DosS from Mycobacterium tuberculosis. J. Biol. Chem. 2009, 284, 13057-13067. [CrossRef]

85. Ioanoviciu, A.; Meharenna, Y.T.; Poulos, T.L.; Ortiz de Montellano, P.R. DevS oxy complex stability identifies this heme protein as a gas sensor in Mycobacterium tuberculosis dormancy. Biochemistry 2009, 48, 5839-5848. [CrossRef]

86. Podust, L.M.; Ioanoviciu, A.; Ortiz de Montellano, P.R. 2.3 A X-ray structure of the heme-bound GAF domain of sensory histidine kinase DosT of Mycobacterium tuberculosis. Biochemistry 2008, 47, 12523-12531. [CrossRef] [PubMed]

87. Basudhar, D.; Madrona, Y.; Yukl, E.T.; Sivaramakrishnan, S.; Nishida, C.R.; Moenne-Loccoz, P.; Ortiz de Montellano, P.R. Distal Hydrogen-bonding Interactions in Ligand Sensing and Signaling by Mycobacterium tuberculosis DosS. J. Biol. Chem. 2016, 291, 16100-16111. [CrossRef]

88. Yukl, E.T.; Ioanoviciu, A.; de Montellano, P.R.; Moenne-Loccoz, P. Interdomain interactions within the two-component heme-based sensor DevS from Mycobacterium tuberculosis. Biochemistry 2007, 46, 9728-9736. [CrossRef] [PubMed]

89. Lobao, J.; Gondim, A.C.S.; Guimaraes, W.G.; Gilles-Gonzalez, M.A.; Lopes, L.G.F.; Sousa, E.H.S. Oxygen triggers signal transduction in the DevS (DosS) sensor of Mycobacterium tuberculosis by modulating the quaternary structure. FEBS J. 2019, 286, 479-494. [CrossRef]

90. Skalova, T.; Lengalova, A.; Dohnalek, J.; Harlos, K.; Mihalcin, P.; Kolenko, P.; Stranava, M.; Blaha, J.; Shimizu, T.; Martinkova, M. Disruption of the dimerization interface of the sensing domain in the dimeric heme-based oxygen sensor AfGcHK abolishes bacterial signal transduction. J. Biol. Chem. 2020, 295, 1587-1597. [CrossRef] 
91. Burns, J.L.; Rivera, S.; Deer, D.D.; Joynt, S.C.; Dvorak, D.; Weinert, E.E. Oxygen and Bis $\left(3^{\prime}, 5^{\prime}\right)$-cyclic Dimeric Guanosine Monophosphate Binding Control Oligomerization State Equilibria of Diguanylate Cyclase-Containing Globin Coupled Sensors. Biochemistry 2016, 55, 6642-6651. [CrossRef] [PubMed]

92. Sousa, E.H.; Lopes, L.G.; Gonzalez, G.; Gilles-Gonzalez, M.A. Drug discovery targeting heme-based sensors and their coupled activities. J. Inorg. Biochem. 2017, 167, 12-20. [CrossRef]

93. Sandner, P.; Zimmer, D.P.; Milne, G.T.; Follmann, M.; Hobbs, A.; Stasch, J.P. Soluble Guanylate Cyclase Stimulators and Activators. Handb. Exp. Pharmacol. 2021, 264, 355-394. [CrossRef] [PubMed]

94. Muniz Carvalho, E.; Silva Sousa, E.H.; Bernardes-Génisson, V.; Gonzaga de França Lopes, L. When NO Is not Enough: Chemical Systems, Advances and Challenges in the Development of NO and HNO Donors for Old and Current Medical Issues. Eur. J. Inorg. Chem. 2021, 2021, 4316-4348. [CrossRef]

95. Ko, F.N.; Wu, C.C.; Kuo, S.C.; Lee, F.Y.; Teng, C.M. YC-1, a novel activator of platelet guanylate cyclase. Blood 1994, 84, 4226-4233. [CrossRef]

96. Sa, D.S.; Fernandes, A.F.; Silva, C.D.; Costa, P.P.; Fonteles, M.C.; Nascimento, N.R.; Lopes, L.G.; Sousa, E.H. Non-nitric oxide based metallovasodilators: Synthesis, reactivity and biological studies. Dalton Trans. 2015, 44, 13633-13640. [CrossRef]

97. He, B.; Chen, Z. Molecular Targets for Small-Molecule Modulators of Circadian Clocks. Curr. Drug Metab. 2016, 17, 503-512. [CrossRef] [PubMed]

98. Ellermann, M.; Sperandio, V. Bacterial signaling as an antimicrobial target. Curr. Opin. Microbiol. 2020, 57, 78-86. [CrossRef] [PubMed]

99. Wille, J.; Coenye, T. Biofilm dispersion: The key to biofilm eradication or opening Pandora's box? Biofilm 2020, 2, 100027. [CrossRef]

100. Cai, Y.M.; Webb, J.S. Optimization of nitric oxide donors for investigating biofilm dispersal response in Pseudomonas aeruginosa clinical isolates. Appl. Microbiol. Biotechnol. 2020, 104, 8859-8869. [CrossRef] [PubMed]

101. da Silva Filho, P.M.; Andrade, A.L.; Lopes, J.; Pinheiro, A.A.; de Vasconcelos, M.A.; Fonseca, S.; Lopes, L.G.F.; Sousa, E.H.S.; Teixeira, E.H.; Longhinotti, E. The biofilm inhibition activity of a NO donor nanosilica with enhanced antibiotics action. Int. J. Pharm. 2021, 610, 121220. [CrossRef]

102. Howlin, R.P.; Cathie, K.; Hall-Stoodley, L.; Cornelius, V.; Duignan, C.; Allan, R.N.; Fernandez, B.O.; Barraud, N.; Bruce, K.D.; Jefferies, J.; et al. Low-Dose Nitric Oxide as Targeted Anti-biofilm Adjunctive Therapy to Treat Chronic Pseudomonas aeruginosa Infection in Cystic Fibrosis. Mol. Ther. 2017, 25, 2104-2116. [CrossRef] [PubMed]

103. Boce, M.; Tasse, M.; Mallet-Ladeira, S.; Pillet, F.; Da Silva, C.; Vicendo, P.; Lacroix, P.G.; Malfant, I.; Rols, M.P. Effect of trans(NO, $\mathrm{OH})-[\mathrm{RuFT}(\mathrm{Cl})(\mathrm{OH}) \mathrm{NO}](\mathrm{PF} 6)$ ruthenium nitrosyl complex on methicillin-resistant Staphylococcus epidermidis. Sci. Rep. 2019, 9, 4867. [CrossRef] [PubMed]

104. Zheng, H.; Abramovitch, R.B. Inhibiting DosRST as a new approach to tuberculosis therapy. Future Med. Chem. 2020, 12, 457-467. [CrossRef]

105. Gupta, R.K.; Thakur, T.S.; Desiraju, G.R.; Tyagi, J.S. Structure-based design of DevR inhibitor active against nonreplicating Mycobacterium tuberculosis. J. Med. Chem. 2009, 52, 6324-6334. [CrossRef]

106. Kaur, K.; Taneja, N.K.; Dhingra, S.; Tyagi, J.S. DevR (DosR) mimetic peptides impair transcriptional regulation and survival of Mycobacterium tuberculosis under hypoxia by inhibiting the autokinase activity of DevS sensor kinase. BMC Microbiol. 2014, 14, 195. [CrossRef] [PubMed]

107. Dhingra, S.; Kaur, K.; Taneja, N.K.; Tyagi, J.S. DevR (DosR) binding peptide inhibits adaptation of Mycobacterium tuberculosis under hypoxia. FEMS Microbiol. Lett. 2012, 330, 66-71. [CrossRef]

108. Zheng, H.; Colvin, C.J.; Johnson, B.K.; Kirchhoff, P.D.; Wilson, M.; Jorgensen-Muga, K.; Larsen, S.D.; Abramovitch, R.B. Inhibitors of Mycobacterium tuberculosis DosRST signaling and persistence. Nat. Chem. Biol. 2017, 13, 218-225. [CrossRef]

109. Zheng, H.; Williams, J.T.; Aleiwi, B.; Ellsworth, E.; Abramovitch, R.B. Inhibiting Mycobacterium tuberculosis DosRST Signaling by Targeting Response Regulator DNA Binding and Sensor Kinase Heme. ACS Chem. Biol. 2020, 15, 52-62. [CrossRef]

110. Patel, Y.S.; Mistry, N.; Mehra, S. Repurposing artemisinin as an anti-mycobacterial agent in synergy with rifampicin. Tuberculosis 2019, 115, 146-153. [CrossRef] [PubMed]

111. Choi, W.H. Novel Pharmacological Activity of Artesunate and Artemisinin: Their Potential as Anti-Tubercular Agents. J. Clin. Med. 2017, 6, 30. [CrossRef]

112. Wan, X.; Tuckerman, J.R.; Saito, J.A.; Freitas, T.A.; Newhouse, J.S.; Denery, J.R.; Galperin, M.Y.; Gonzalez, G.; Gilles-Gonzalez, M.A.; Alam, M. Globins synthesize the second messenger bis- $\left(3^{\prime}-5^{\prime}\right)$-cyclic diguanosine monophosphate in bacteria. J. Mol. Biol. 2009, 388, 262-270. [CrossRef]

113. Sarkar, J.; Miller, D.P.; Oliver, L.D.; Marconi, R.T. The Treponema denticola PAS Domain-Containing Histidine Kinase Hpk2 Is a Heme Binding Sensor of Oxygen Levels. J. Bacteriol. 2018, 200, e00116-e00118. [CrossRef]

114. Sen Santara, S.; Roy, J.; Mukherjee, S.; Bose, M.; Saha, R.; Adak, S. Globin-coupled heme containing oxygen sensor soluble adenylate cyclase in Leishmania prevents cell death during hypoxia. Proc. Natl. Acad. Sci. USA 2013, 110, 16790-16795. [CrossRef]

115. Abuchowski, A. SANGUINATE (PEGylated Carboxyhemoglobin Bovine): Mechanism of Action and Clinical Update. Artif. Organs 2017, 41, 346-350. [CrossRef] 
116. Azarov, I.; Wang, L.; Rose, J.J.; Xu, Q.; Huang, X.N.; Belanger, A.; Wang, Y.; Guo, L.; Liu, C.; Ucer, K.B.; et al. Five-coordinate H64Q neuroglobin as a ligand-trap antidote for carbon monoxide poisoning. Sci. Transl. Med. 2016, 8, 368ra173. [CrossRef]

117. Hoops, H.E.; Manning, J.E.; Graham, T.L.; McCully, B.H.; McCurdy, S.L.; Ross, J.D. Selective aortic arch perfusion with fresh whole blood or HBOC-201 reverses hemorrhage-induced traumatic cardiac arrest in a lethal model of noncompressible torso hemorrhage. J. Trauma Acute Care Surg. 2019, 87, 263-273. [CrossRef]

118. Alam, M.; Larsen, R. Heme Proteins hemAT-Hs and hemAT-Bs and Their Use in Medicine and Microsensors. U.S. Patent 7,129,329, 31 October 2006.

119. Boehme, J.; Le Moan, N.; Kameny, R.J.; Loucks, A.; Johengen, M.J.; Lesneski, A.L.; Gong, W.; Goudy, B.D.; Davis, T.; Tanaka, K.; et al. Preservation of myocardial contractility during acute hypoxia with OMX-CV, a novel oxygen delivery biotherapeutic. PLoS Biol. 2018, 16, e2005924. [CrossRef]

120. Itoh, T.; Matsuura, S.I.; Chuong, T.T.; Tanaike, O.; Hamakawa, S.; Shimizu, T. Successful Mesoporous Silica Encapsulation of Optimally Functional EcDOS (E. coli Direct Oxygen Sensor), a Heme-based $\mathrm{O}_{2}$-Sensing Phosphodiesterase. Anal. Sci. 2019, 35, 329-335. [CrossRef]

121. Kalia, D.; Merey, G.; Nakayama, S.; Zheng, Y.; Zhou, J.; Luo, Y.; Guo, M.; Roembke, B.T.; Sintim, H.O. Nucleotide, c-di-GMP, c-di-AMP, cGMP, cAMP, (p)ppGpp signaling in bacteria and implications in pathogenesis. Chem. Soc. Rev. 2013, 42, 305-341. [CrossRef]

122. Opoku-Temeng, C.; Sintim, H.O. Targeting c-di-GMP Signaling, Biofilm Formation, and Bacterial Motility with Small Molecules. Methods Mol. Biol. 2017, 1657, 419-430. [CrossRef]

123. Wang, J.; Karpus, J.; Zhao, B.S.; Luo, Z.; Chen, P.R.; He, C. A selective fluorescent probe for carbon monoxide imaging in living cells. Angew. Chem. Int. Ed. Engl. 2012, 51, 9652-9656. [CrossRef]

124. Winter, M.B.; McLaurin, E.J.; Reece, S.Y.; Olea, C., Jr.; Nocera, D.G.; Marletta, M.A. Ru-porphyrin protein scaffolds for sensing $\mathrm{O}_{2}$ J. Am. Chem. Soc. 2010, 132, 5582-5583. [CrossRef]

125. Nierth, A.; Marletta, M.A. Direct meso-Alkynylation of Metalloporphyrins Through Gold Catalysis for Hemoprotein Engineering. Angew. Chem. Int. Ed. 2014, 53, 2611-2614. [CrossRef]

126. Lemon, C.M.; Marletta, M.A. Corrole-Substituted Fluorescent Heme Proteins. Inorg. Chem. 2021, 60, 2716-2729. [CrossRef] [PubMed]

127. Fardeau, M.L.; Salinas, M.B.; L'Haridon, S.; Jeanthon, C.; Verhe, F.; Cayol, J.L.; Patel, B.K.C.; Garcia, J.L.; Ollivier, B. Isolation from oil reservoirs of novel thermophilic anaerobes phylogenetically related to Thermoanaerobacter subterraneus: Reassignment of T. subterraneus, Thermoanaerobacter yonseiensis, Thermoanaerobacter tengcongensis and Carboxydibrachium pacificum to Caldanaerobacter subterraneus gen. nov., sp. nov., comb. nov. as four novel subspecies. Int. J. Syst. Evol. Microbiol. 2004, 54, 467-474. [CrossRef] [PubMed]

128. Dai, Z.; Boon, E.M. Engineering of the heme pocket of an H-NOX domain for direct cyanide detection and quantification. J. Am. Chem. Soc. 2010, 132, 11496-11503. [CrossRef]

129. Winter, M.B.; Klemm, P.J.; Phillips-Piro, C.M.; Raymond, K.N.; Marletta, M.A. Porphyrin-substituted H-NOX proteins as high-relaxivity MRI contrast agents. Inorg. Chem. 2013, 52, 2277-2279. [CrossRef]

130. Kumita, H.; Yamada, S.; Nakamura, H.; Shiro, Y. Chimeric sensory kinases containing $\mathrm{O}_{2}$ sensor domain of FixL and histidine kinase domain from thermophile. Biochim. Biophys. Acta 2003, 1646, 136-144. [CrossRef]

131. Moglich, A.; Ayers, R.A.; Moffat, K. Design and signaling mechanism of light-regulated histidine kinases. J. Mol. Biol. 2009, 385, 1433-1444. [CrossRef]

132. Iniesta, A.A.; Hillson, N.J.; Shapiro, L. Cell pole-specific activation of a critical bacterial cell cycle kinase. Proc. Natl. Acad. Sci. USA 2010, 107, 7012-7017. [CrossRef]

133. Nomata, J.; Hisabori, T. Development of heme protein based oxygen sensing indicators. Sci. Rep. 2018, 8, 11849. [CrossRef]

134. Ainala, S.K.; Seol, E.; Sekar, B.S.; Park, S. Improvement of carbon monoxide-dependent hydrogen production activity in Citrobacter amalonaticus Y19 by over-expressing the CO-sensing transcriptional activator, CooA. Int. J. Hydrog. Energ. 2014, 39, 10417-10425. [CrossRef]

135. Arnold, F.H. Innovation by Evolution: Bringing New Chemistry to Life (Nobel Lecture). Angew. Chem. Int. Ed. Engl. 2019, 58, 14420-14426. [CrossRef]

136. Leveson-Gower, R.B.; Mayer, C.; Roelfes, G. The importance of catalytic promiscuity for enzyme design and evolution. Nat. Rev. Chem. 2019, 3, 687-705. [CrossRef]

137. Aggrey-Fynn, J.E.; Surmeli, N.B. A novel thermophilic hemoprotein scaffold for rational design of biocatalysts. J. Biol. Inorg. Chem. 2018, 23, 1295-1307. [CrossRef]

138. Ortmayer, M.; Lafite, P.; Menon, B.R.; Tralau, T.; Fisher, K.; Denkhaus, L.; Scrutton, N.S.; Rigby, S.E.; Munro, A.W.; Hay, S.; et al An oxidative N-demethylase reveals PAS transition from ubiquitous sensor to enzyme. Nature 2016, 539, 593-597. [CrossRef] [PubMed]

139. Woodward, J.J.; Martin, N.I.; Marletta, M.A. An Escherichia coli expression-based method for heme substitution. Nat. Methods 2007, 4, 43-45. [CrossRef] [PubMed]

140. Kawakami, N.; Shoji, O.; Watanabe, Y. Single-step reconstitution of apo-hemoproteins at the disruption stage of Escherichia coli cells. Chembiochem 2012, 13, 2045-2047. [CrossRef] [PubMed] 
141. Lelyveld, V.S.; Brustad, E.; Arnold, F.H.; Jasanoff, A. Metal-substituted protein MRI contrast agents engineered for enhanced relaxivity and ligand sensitivity. J. Am. Chem. Soc. 2011, 133, 649-651. [CrossRef]

142. Perkins, L.J.; Weaver, B.R.; Buller, A.R.; Burstyn, J.N. De novo biosynthesis of a nonnatural cobalt porphyrin cofactor in E. coli and incorporation into hemoproteins. Proc. Natl. Acad. Sci. USA 2021, 118, e2017625118. [CrossRef] 